\title{
Environmental Democracy in a European Context
}

\section{Section I: Environmental Democracy in the European Union}

"If citizens' participation is the "lifeblood" of democracy, then the European Union suffers from anaemia and is in desperate need for a

remedy" (Abels, 2008).

\section{1. "Democracy" and "Environment" in the European Union}

\section{1. "Democracy"}

As it is well known, the EU is a new type of organisation:4 it is not a state nor is it a nation, but it is more than a common market and it is not merely an intergovernmental organisation that solves the problems of the Member States.

When the European Economic Community was created in 1957, the question of the democratic nature of the new organisation was not a matter of serious concern and could be assumed to be "absorbed" by the democratic credentials of the delegating Member States..$^{5}$ In fact, the initial European Communities

4 There is, in fact, a considerable body of literature on the nature of the Community, how it has evolved, and its future direction. See, on this point, Craig, \& De Burca, 2008; Cremona, 2004, p. 553; See also Bankowski, \& Christodoulidis, 1998, p. 341. On the European constitutionalization process: Von Bogdandy, 2005, p. 913; Wessels, \& Diedrichs, 1997.

5 There are also disagreements among scholars about its nature. "Is it a functional intergovernmental cooperation mechanism between Member States? Is it a 'supranational community' of shared values and 'constitutional tolerance'? Maybe an experiment in the cosmopolitan ideals of a 'post-national' or a 'pluralistic' polity? Or is it a technocratic 
were based on a "permissive consensus" (Lindberg, \& Scheingold, 1970, p. 41; Smismans, 2009), and since then, little by little, it has become a polity which performs functions that affect the interests and identities of the European citizens as well as the Member States. Hence, the EU started to feel a lack of democratic basis and understood that it could no longer draw on indirect legitimacy. Consequently, it tried to establish direct links with its citizens, increasing its structures and processes in a more democratic way, in particular through participatory mechanisms.

The intention here is not to advocate one of the myriad approaches to democracy in Europe, but to try to identify how EU law is dealing with the problem of democratic deficit, or as some authors have called it with an "infringed popular will" (Zampetti, 1995, p. 11), and which solutions it has already found (Balme, \& Chanet, 2008).

\subsubsection{Democratic Deficit in the EU}

To start, it is interesting to recall what Beck wrote arguing that "if the EU were to apply for membership of the EU it would be rejected because of its lack of democratic structures!" (Beck, 1998).

This joke comes from a real deficit of democracy, which has been remarked upon for a long time by most scholars, ${ }^{6}$ who define democratic deficit, even if not by all,7 as a "myth propagated by eurosceptic circles" (Moussis, 2009, p.

'problem-solving agent' established to solve the transnational governance problems of an economic and technocratic nature? The technocratic vision has indeed, for a long time, dominated both the public and scholarly debate on the EC/EU: is it an elite game in the hands of economic interests and bureaucrats?": see Rodriquez, 2008, p. 24.

6 The public debates on democracy became prominent in the period preceding and immediately following the negotiations for the Maastricht Treaty, which "notwithstanding high hopes, and indeed some progress, notably failed to address these questions" (De Burca, 1996, p. 349) and eighteen years later, the debate is as lively as ever. Lee, 2003, p. 195.

7 A word must be said about the position which denies a democratic deficit. Following two approaches there is no democratic legitimacy deficit: firstly the community only executes closely circumscribed functional decisions, which member states have agreed to by democratic means. This view has been defended by Majone who consider the EU as a 'regulatory state' (Majone, 1996). "Regulatory policies, such as competition policy, the removal of trade barriers or monetary policy, are destined to address and redress market failures. For those policies to be effective, they have to be taken in an undemocratic fashion in the sense that they are excluded from the adversarial power play of parliamentary, majoritarian politics. Otherwise, decisions would be unduly politicised whereby their credibility and Pareto-efficient effects would be undermined and the Eu's (out) legitimacy would suffer". (Majone, 2000, p. 273; Majone, 2002, p. 319).

For H.-Peter IPSEN the then EC constitutes a regulatory agency "our fourth branch of government which fulfils clearly specified functional goals and hence offers no room for 
145). Nevertheless, most authors judge that even though democratic structures are in place at the EU level, such as a directly elected parliament, the EU has a democratic deficit. Dahl, one of the most famous democratic theorists even calls it "gigantic" (Dahl, 1998, p. 115).

Although the term "democratic deficit" encompasses a number of different features, ${ }^{8}$ for current purposes it is worth noting that it is possible to identify two principal elements, one linked to the other and both underpinning the democratic deficit of the EU: first there is the issue relating to transparency and second to the legitimacy of decisions.

The transparency problem emerged from the influence of the "administrative tradition of continental Europe" (Jendroska, 2006, p. 63) where access to governmental information and public participation in decision-making was not known to many European administrative cultures and where their custom of secrecy was used to block a possible citizens' involvement.

The role of the individual was narrow, merely entailing the right to vote: and this was the only kind of relationship between the state and its citizens. In fact, the state was considered for a long time as "a structure which expresses and creates the unity of the nation rather than as a forum for the competition of

political discretion". (Kohler-Kock, \& Rittberger, 2007b, p. 4); secondly some authors assert individuals are better off from a rights perspective. According to Ernst-Joachim Mestmacker the community is set up on an economic constitution which derives its legitimation from the creation of a free market and the notion of free movement which empowers individuals as it extends their individual rights and freedoms (Mestmacker, 1994, p. 615). Mestmacker concludes that "as long as political procedures are consistent with existing national democratic practice and have a prima facie normative justification [...] we cannot draw negative conclusions about the legitimacy of the EU from casual observation of the non-participatory nature of its institutions". Mestmacker, 1994, p. 622.

See also Majone, 1998, p. 5; Crum, 2005, p. 452. On the matter, see also Craig, 1997, p. 105.

8 In 1996 Craig and Burca (1999, p. 23) distinguished among a number of reasons to explain what it was democratic deficit: "There is what may be termed the distance issues. The existence of the Community has involved the transfer of competence on many issues to Brussels and away from the nation state. This has meant that, in a literal sense, matters are further removed from the citizens. It has also been a factor in questioning the Community's legitimacy: Why should 'those people over there be making decisions which affect me over here?' [...] An equally important facet of the democracy deficit argument is the executive dominance issue. The transfer of competence to the Community enhances the power of the executive at the expense of parliamentary bodies. [...]. A third feature of the democratic deficit is the by-passing of democratic argument. This is applied most frequently to the operation of the EC's complex committee structure, known generally as comitology. Many technical, but important, regulations are made by committees established pursuant to a delegation of power to the commission [...]. A fourth aspect of democracy deficit can be termed the transparency and complexity issue. Traditionally much of the decision-making of the community, particularly that of the council has taken place behind closed doors. In addition the very complexity of the legislative procedures means that it is virtually impossible for anyone, other than an expert to understand them". 
different interests of individuals, social groups and organisations" (Jendroska, 2006, p. 63).

Consequently, the law was understood as a "common interest"; in other words, the interest of the whole society and not an outcome of a social compromise between the interests of different groups. In fact, European societies were not accustomed to considering the relationship between the state and its citizens in "contractual terms" (Jendroska, 2005, p. 12).

Hence, this traditional approach has been maintained at the national level until not so long ago and still influences the European level (Roberts, 2002, p. 255). It has been proposed that the secrecy approach is not beneficial or justifiable anymore, in particular because almost all of the members which influenced this custom have already changed their own secrecy approach, responding to the new expectations and demands coming from society, and thus, they are moving towards a concept of open governance.

Nevertheless, it is worth noting that the perception that "secrecy leads to mistrust, and that openness is the way to regain public confidence in government action" has appeared also in EU discussions and policies concerning public participation for a long time (Roberts, 2002, p. 255). An example is the access to information in the EU, which has moved "from a culture of secrecy, relating to the diplomatic nature of international decision-making, through voluntary initiatives, to formal legal obligations of access to Community documents" (Lee, 2005, p. 127-128). Indeed the introduction at the EU level of legislation on general access to documents, as will be shown in the following sections, seems to assume that openness has an inherent value, and is related to making decisions close to the citizens' interests.

The second component of democratic deficit attributed to the EU as well as to domestic policy-making is essentially an "accountability and legitimacy deficit" (Heinel, 2007, p. 224). This is a complex debate, embracing different issues: first the European project itself does not have the support of the European people; and second, there is a concern that the methods and procedures by which the EU institutions reach decisions are not subject to democratic principles (Lee, 2003, p. 207).

The reason for the situation as described above is that at the time of its foundation and in the earlier stages of its development, European integration was "largely an elite project" (Lee, 2003, p. 207), hence, EU decision-making was a matter for high officials. Government ministers and citizens had no formal participatory role.

Nevertheless, the situation has started to change since the EU has been taking a deeper interest in the European citizens and also has introduced the theories of "Direct effect" and "Supremacy", as defined by the European Court of 
Justice (ECJ). ${ }^{9}$ The consequences of EU action in more policy areas and the daily

9 The EEC Treaty, signed in Rome on 25 March 1957, was mainly aimed at economic progress. Expression of other aims was, however, in its preambles, which posted economic integration as a means to a better end, rather than as the sole end in itself. The material limits of the Community jurisdiction were not precisely defined by the Treaty. Nevertheless, the relatively open provisions and the aims stated in the preambles of the Treaty gave the EC] extensive possibilities for a broad and instrumentalist interpretation of Community Law. Mechanisms of enforcing EC laws have evolved in an attempt to provide ways which enable the law of this international Treaty to be respected by the signatory Member States (MS) and enforceable by the individuals in that State to whom these obligations and rights are applicable. These mechanisms began with Direct Effect whereby the primary laws of the Treaty could be given effect directly in the MS' domestic courts. The question regarding Direct Effect first arose in 1956 in relation to the ECSC Treaty, but was later posed on a much larger scale within the framework on the EEC Treaty, when the Court passed its ground breaking judgment Van Gend en Loos (Case 26/62, NV Algemene Transport- en Expeditie Onderneming van Gend en Loos v. Nederlandse Administratie der Belastingen [1963] ECR 1). The Court stated: "The Community constitutes a new legal order of international law for the benefit of which the States have limited their sovereign rights, albeit within limited fields, and the subjects of which comprise not only MS but also their nationals. Independently of the legislation of MS, Community law therefore not only imposes obligations on individuals but is also intended to confer upon them rights which become part of their legal heritage. These rights arise not only where they are expressly granted by the Treaty, but also by reason of obligations which the Treaty imposes in a clearly defined way upon individuals as well as upon MS and upon the Institutions of the Community". Then the Court set up four conditions for the Direct Effect of Treaty provisions: it must be clear, unconditional, containing no reservation on the part of the Member State, and not dependent on any national implementing measure.

One year later, in the Case Costa v. ENEL (Case 6/64, Flamino Costa v. ENEL [1964] ECR 585.) the Court affirmed and developed its constitutional theory of the Community where the national law was in conflict with a provision of EC law. In this case the Court concluded that Community law had to be given primacy by national Courts over any incompatible national law Subsequently other cases developed the doctrines of Direct Effect and supremacy into firmly embodied foundations of EC law (Case 11/70 Internationale Handelsgesellschaft mbH v. Einfuhr- und Vorratsstelle für Getreide und Futtermittel [1970] ECR 1125; Case 106/77, Amministrazione delle Finanze dello Stato v. Simmenthal SpA [1978] ECR 629, [1978] 3).

Subsequently also the enforcement mechanisms of Direct Effect and Indirect Effect were not successful in ensuring EC laws were being upheld and observed, and the distinction between Horizontal Direct Effect and Vertical Direct Effect was "causing potential embarrassment for the validity of this method of enforcing EC rights" (There was then the extension of doctrine of Direct Effect to secondary laws such as Directives (Spa SACE v. Italian Ministry of Finance, Case 33/70) [1970] ECR 1213), but limited to the Vertical direction; this was followed by the enforcement mechanism of Indirect Effect (Von Colson v. Land Nordrhein-Westfalen (Case 14/83) [1984] ECR 1891), which was necessary as a consequence of the EC] not allowing Direct Effect to be used Horizontally and is a process of purposive statutory interpretation (Litster v. Forth Dry Dock and Engineering Co. Ltd 1 All ER 1134; [1990] 1 A.C. 546"). In fact the 'useful effect' (from the French effet utile) rationale for Direct Effect requires a remedy where private individuals fail to respect provisions of EC law. The EC] recognised problems it had in ensuring EC law was being followed as required and had been widely criticised by academics and other commentators for denying Horizontal Direct Effect. It hence established the alternative remedy of State Liability to alleviate these criticisms. To circumvent the limitations of the doctrine of horizontal Direct 
impact of the European integration process put forth evidence that merely the EU structure remains unsatisfying for addressing the legitimacy of the European construction (Smismans, 2009).

Until the need to participate at an EU level and the possibility for citizens to exert influence over the policies which affect their daily lives is recognised, the democratic deficit will continue to persist (Parry, 2010).

\subsubsection{The Remedies of Democratic Deficit}

So, how can this European democratic deficit be remedied? The democratic deficit approach is divided between doctrines which see the democratic deficit "virtually insurmountable given the inherent limitations in the EU's democratic capacity" and those "who claim that it can be resolved or at least attenuated through constitutional engineering in the short to medium term" (Kohler-Kock, \& Rittberger, 2007a, p. 1).

The EU has tried to answer to the democratic deficit by undertaking different paths. In particular, two measures have been put into place to implement the slogan 'Europe closer to the citizens' 10 : first, the extension of control through representative tools, and the extension of the roles of the National Parliament and European Parliament in decision-making. The second involves deliberative and participative measures to increase the opportunities for public involvement in EU decision-making (Hallo, 2008, pp. 10-11). For instance, internet consultations as well as other measures to grant the participative right via the right of access to documents held by Community institutions. ${ }^{11}$

As will be explained in the following section, it was only recently that Europe started with these above-mentioned ways, reforming the system and consequently departing from the traditional "thin democracy" towards a more

Effect, the EC] developed a general principle of state responsibility for compliance with EC law. State liability derives from the fact that EU MS, or emanations of the state, are responsible for the creation and above all for the implementation and enforcement of EC law. Many EU rights, particularly those in the many Directives in the fields of employment and industrial relations, are enforced through the doctrine of Direct Effect of Directives. This doctrine was created by a case in the field of employment rights: Francovich and Others v. Italian Republic. (Cases C-6 and 9/90 Francovich and Bonifaci v. Italy [1991] ECR I-5357. See Caranta, 1993, p. 272; Craig, 1996, p. 399; Harlow, 1996, p. 199; Parker, 1992, p.181; ROSS, 1993, p. 55. See also Anagnostaras, 2001, p. 281; Thorvaldsson, 2002.

10 The slogan has been mentioned in the programme Europe for Citizens available at www.europeforcitizens.ie

11 This right was introduced to the EC Treaty in 1999, Article 255, and specified in Regulation 1049/2001 regarding public access to European Parliament, council and commission documents, O] 2001, L 145, p.43. Hallo, 2008, pp.10-11; Hallo, 2007; See also Heinelt, 2007, p. 224. 
open government. This changed approach, more deliberative and participatory, was influenced by many factors, one important factor being the need for environmental protection. As has been underlined, it is not a coincidence that environmental law was the first to recognise procedural rights within the EU (Jendroska, 2006, p. 63).

\subsubsection{Representative Democracy Tools}

Whether representative democracy is the ultimate legitimation of the legislative and administrative process or a symbol of governance according to the will of the people (Mathiesen, 2003, p. 36), both the European Parliament and National Parliaments are potential reform targets to "alleviate the democratic legitimacy deficit" (Rittberger, 2007, p. 133).

Thus, the initial concern for the 'democratic deficit' of the EU focused on the need of a popular involvement via the European Parliament. Such direct parliamentary representation of European citizens was introduced by direct elections for the European Parliament in 1979, and subsequent changes increased its powers - budgetary and legislative powers (from consultation to co-operation and co-decision procedure), and control over the Commission.

Moreover, the Parliament has increased its influence in the European lawmaking process, through expansion of the co-decision procedure under former Article 252 of the EC Treaty, which has become the standard procedure through which regulations and directives are deliberated and decided upon, and in which the Parliament is assigned a veto power, and in that sense, a co-legislative role. ${ }^{12}$ Furthermore, a significant change made by the Lisbon Treaty ${ }^{13}$ concerns an extension of the decision-making powers of the European Parliament as well. Co-decision is henceforth known as the ordinary legislative procedure and has been expanded to more policy areas leaving few over which the Parliament only enjoys a consultative role. ${ }^{14}$

Although the expansion of the role of the European Parliament to decrease the democratic deficit was useful, an element is missing: namely, a European

12 Rodriquez, 2008, p. 24; On this issue, see amplius Menendez, 2005, p. 105. On the co-decision procedure, see Pennera, \& Schoo, 2004, p. 531. On the co-decision procedure as laid down in the Treaty establishing a Constitution for the Union, see Daswood, \& Johnston, 2004, p. 1481. On this issue, see Farrell, \& Heritier, 2002.

13 As of the Treaty of Lisbon (2007) (OJ 2007 C 306/01), in force 1 Dec. 2009, the European Union replaces and succeeds the European Community.

14 Although most environmental policy is already subject to co-decision making environmentally related areas in which the new 'ordinary legislative procedure' applies include aspects of transport, energy, fisheries, external trade, regional and agricultural policy. Benson, \& Jordan, 2008, p. 280. 
demos which could provide the basis for a parliamentary expression of democracy. Indeed, the parliamentary model is based on an expression of the general will and in order to deduce such, the governed who are represented in parliament should have a certain level of social unity and a common identity; that is, a general acceptance of the 'idea of Europe' and "a commitment to the shared values of the Union as expressed in its constituent documents" (Kaelble, 1994, p. 27; Weile, 1997, p. 249).

For some authors, there is no such common identity in the EU, and, as Article 1 of the EU Treaty states, the EU is still based on a process of integration "among the peoples of Europe". The creation of a common identity seems to crystallise very slowly (Risse, 2002), and because of this a European 'public sphere' in which citizens are informed on, and take part in political discussions does not exist; also, a truly European media remains lacking. Communication on European issues which is not nationally coloured is a further default, complicated by being split into different languages.

Moreover, European political parties are weak and turnout in EP elections is uneven and low (Smismans, 2009; 2003, p. 473; 2004, p. 122). Although interest groups ought to expand their action to the European level, they remain mainly national interest groups.

Some authors see the expansion of the control and role of National Parliaments as a remedy for this democratic deficit, constituting a growing involvement of National Parliaments in EU policy-making. The main reason of this idea is that the National Parliaments should formulate the will of the Member States' people (Auel, \& Benz, 2007, p. 57) 15 $^{15}$ and it is "the most important mechanism linking the citizens to the EU, because it translates the views of the citizens into European policy" (Andeweg, 2007, p. 102). Furthermore, since the Lisbon Treaty has been ratified, National Parliaments have a more direct role, as they can block European legislative initiatives for not respecting subsidiarity. However, the threshold for them to be able to do so is high because one third of all National Parliaments need to vote in this sense within a short time limit of eight weeks.

Despite all of these means found within the representative democracy model being somewhat useful in avoiding part of the democratic deficit, they are nevertheless insufficient to improve and create democratic accountability in the European Union (Smismans, 2009). Indeed, the improvement of representative democracy in Europe addresses only part of the issues relating to the democratic deficit. A territorially elected parliament cannot represent the whole of its electorate's personalities and interests, given that individuals are potentially

15 See also Maurer, 2007, p. 75. 
infinite in their purpose and wills, in particular if this election is a European election.

Thus, something more is therefore needed: democracy must become more inter-active with citizen participation in the current debates. In this respect, a continuous role of individuals is vital and the involvement of civil society organisations (Smismans, 2003, p. 473) 16 $^{16}$ my also constitute a step towards greater and more effective participation in the $\mathrm{EU}$ and an improvement of openness (Parry, 2010). If in a democracy, sovereignty ultimately rests with the individual citizen, then their political leaders have a duty to involve them in what is happening in their name.

Then the most efficient tool to decrease the democratic deficit and strengthen the link among citizens is to increase public participation with the final aim of creating the basis for constructing a European demos. The Lisbon Treaty, which in some way is taking this path, reinforces the significance of 'participation' in political life generally.

In summary, it can be said that participatory mechanisms through which citizens are able to act can serve as a complementary mechanism to traditional parliamentary representation. (Smismans, 2009)

\subsubsection{Participatory and Deliberatory Tools}

Before starting, it is necessary to note that a broad meaning of public participation is appropriate and at the EU level includes "open and transparent procedures and decisions, consultation or more intense involvement in decisions, which could encompass also the element of deliberative democracy" (Lee, 2005, p. 114). Recent years have seen a remarkable consensus concerning the need for participatory democracy in decision-making at the EU level.

16 European civil society can be described as multiform, multi- dimensional and multilevel". Armstrong, 2002, p. 113. By multiform, "we refer to a pluralistic understanding of the forms of civil society moving from the civic participation of the individual, through loose networks of actors, to formalised and enduring organisational structures. By multidimensional, we can think of the different roles played by civil society actors from the promotion of political deliberation, through more, or less, structured processes of consultation and participation (participatory democracy), to direct roles in the de- livery of governance. By multilevel, we mean the inclusion of the diverse structures and traditions of national civil society actors, together with any sub-national and transnational actors. A narrower definition of European civil society would encompass only some of these elements". See Rodriquez, 2008, p. 24. See also Armstrong, 2008. The author recalls the Craig civil society concept: "Civil society, connoting in this context networks, movements, etc., which organise to assert interests outside state-based and controlled political institutions, is accorded an important role in the deliberative process. Participatory democracy is thus seen as starting from the bottom up, from 'groups of people dedicated to the disinterested search for the public interest in society": Craig, 1999, p. 41. 
Despite some authors denying this, ${ }^{17}$ the path towards more participatory procedure is now seen as a possibility to improve the legitimacy of decisionmaking, possessing the potential to provide a response to the disputed democratic deficit of EU law and effectiveness at the EU level. The involvement of individuals in the decision-making process at the European level aims at decreasing the democratic deficit by: "expanding the knowledge base to increase the quality of EU policies; making public administration accountable to society as a whole; achieving an all-embracing mobilisation of political interests and enhancement of direct participation of citizens; creating a trans-national democratic public sphere" (Kohler-Kock, 2007b, p. 255).

Given the limits of understanding EU democracy merely in terms of the parliamentary model, participatory democracy can contribute to EU democracy. Although instances of direct citizen participation will be limited in impact, they are desirable for contributing to a European public sphere. Thus, the objective is therefore to "make Europe more relevant to its citizens", "to regenerate a European spirit" and "to give incentive for a shared willingness to bring forward the European project" (Kohler-Kock, 2004, p. 5).

Indeed there are numerous proposals for the enhancement of democracy by involving the public, and attention is given to a range of alternative participatory instruments, as well as explicit appeals being made for deliberative processes. In order to increase the level of democracy, the creation of a political means that could provide citizens opportunities for participation, influence and control has been suggested (Dahl, 1998, p. 115).

Among different deliberative instruments, the most interesting for this discussion are citizens' forums and citizens' initiatives. One example has been called e-democracy, which by use of electronic consultation processes allows for a new form of direct citizen involvement. The second citizens' initiative will be analysed later.

A collective political identity shared by the peoples in Europe could be necessary, according to some scholars who have commented on introducing these tools, and who also consider that Europe still doesn't have this characteristic, since European states have distinct "national histories each with its own interpretations of the past and own languages" (Kohler-Kock, \& Rittberger, 2007, p. 1 ).

17 Some scholars held that there is no consensus in Europe on the legitimacy of representation outside of political parties and the electoral process and that "without wider agreement, voluntary associations and interest groups should not be given a courtenforced right to participate [...] in Community policy-making", Bignami, 2004, p. 61; See also De Leeuw, 2007, p. 295. 
For other scholars, the above-mentioned deliberative instruments could enhance democracy and civil dialogue. Concerning civil dialogue, it may be noted that European institutions have set up the European Commission and the European Economic and Social Committee which have to achieve this aim. ${ }^{18}$ Civil dialogue is, in fact, considered another "instrument to revitalise civil society, to encourage more social interaction and to create an open and transnational public space, which together form the prerequisite for a European wide civil society". A transnational public space and a "vibrant Pan-European civil society would therefore be the very basis for a thriving European democracy" (KohlerKock, 2004). Thus, enhanced consultation procedures are perceived as a means to remedy also the situation of "governance without government" (Getliffe, 2002, p. 101) that Demmke (Demmke, 1998) describes as the "post-parliamentary age" whereby decisions are taken by committees made up of national civil servants, resulting in reduced levels of transparency.

18 "The origin of civil dialogue is to be found in detail in the development of EU social policy. The language of civil dialogue emerged from debates surrounding the Commission's Green and White Paper on European Social Policy of the early 1990 s and the desire for a broader forum for discussion on the future of social policy. The result was the convening of the first European Social Policy Forum in March 1996. This is often viewed as the start of civil dialogue, bringing together over 1,000 participants mainly from NGOs in the social sphere. The Forum is considered "the launch of a new policy objective: the building over time of a strong civil dialogue at European level to take its place alongside the policy dialogue with the national authorities and the social dialogue with the social partners" (Commission, 'Communication on Promoting the role of voluntary organisations and foundations in Europe', 6 June 1997, COM (97), 241 final). "In its 1997 Communication on Promoting the Role of Voluntary Organisations and Foundations in Europe, the Commission indicated the importance of the Forum for the development of a civil dialogue with the aims of: a) ensuring that "the views and grassroots experience of the voluntary sector can be systematically taken into account by policymakers at the European level so that policies can be tailored more to meet real needs"; b) disseminating "information from the European level down to the local level so that citizens are aware of developments, can feel part of the construction of Europe and can see the relevance of it to their own situation, thus increasing transparency and promoting citizenship". In its Communication on Strategic Objectives (2000-2005), entitled Shaping the New Europe, the Commission claimed that it: Wants to find a new synergy between all the European Union's democratic bodies, as part of a broader improvement of European governance. We want to strike a new balance between action by the Commission, the other institutions, the Member States and civil society. Our aim is to bring Europe much closer to the people. In 2000, the Commission published a Discussion Paper: "The Commission and non-governmental organisations: building a stronger partnership". The paper found its place within the context of an administrative reform of the European Commission established by Commission President Prodi and Vice-President Kinnock in response to problems of legitimacy crisis. It stressed the valuable NGO contribution to the development of legitimate European governance and specified some considerations about the cooperation between the Commission and NGOs and about the role of these organisations", Rodriquez, 2008, p. 24. 


\subsubsection{The Treaty Instruments to Participate}

As a response to the slim victories and defeats in some referenda which were held in the aftermath of the Maastricht Treaty negotiations and the decreasing popular support for the European integration project, ${ }_{1}^{19}$ the European Institutions have tried to find other means of improving democracy. The heads of states and governments called for "a Union closer to the citizens", ${ }^{20}$ because they were aware that classical arrangements, such as political parties, parliamentary assemblies, or other representative bodies, and also the lack of public space, ${ }^{21}$ could no longer provide sufficient mechanisms of democratisation in terms of representing the will of the people.

One initiative which proves this new goal was the well-known "Commission White Paper on European Governance" 2001.22 The message was the necessity to reform European governance connecting "Europe with its citizens" and renewing "the Community method by following a less top-down approach and complementing its policy tools more effectively with non-legislative instruments". ${ }^{23}$

In fact, the White Paper contains elements which "strongly mirror the tenets of the model of advocacy democracy by emphasising the prominence of nonelectoral channels for citizens participation" (Kohler-Kock, \& Rittberger, 2007a, p. 10). In particular, the White Paper recognises five principles underlying the notion of good governance: Openness, Participation, Accountability, Effectiveness

\footnotetext{
19 This data was indicated by the Eurobarometer surveys since the early 1990 s.

20 Turin Council: White Paper on the 1996 Intergovernmental Conference, 29 March 1996, Vol. II, internet.

21 'A 'Public Space' is defined as an arena of communication in which those who govern and those who are subject to governance in a given legally constituted polity gather and express particular interests, concerns, and expectations that interfere with political decision making. So the public space thus initiates a process in which political decision making is mediated through public opinion and collective will formation. In this sense a public space provides a mechanism of democratization. The way in which it distributes chances of access, arena of debates, and links to the institutionalized system of political decision making finally indicates a polity's degree of democratization". See for this definition Eder, \& Trenz, 2007, p.167.

22 On the definition of the term "governance", see European Commission Work Programme, white Paper on European Governance: Enhancing Democracy in the European Union, SEC (2000) 1547/7, 11 October 2000. See Wind, 2009; Jørgensen, 1997; Schout, \& Jordan, 2005, p. 201; Möllers, 2006, p. 313.

23 "The Commission already adhered to that principle when preparing and launching the White Paper: In the preparatory phase it engaged in extensive consultations with representatives of organised interests and the academic community, it organised and stimulated a broad public debate after publication, and since then provides incentives for more thorough investigations on the conditions of the linkages between European citizenship, civil society and EU democracy", Kohler-Kock, \& Rittberger, 2007a, p. 10.
} 
and Coherence. ${ }^{24}$ The first two are most important because they are the main ground on which participative and deliberative democracy can develop and are also the principles to which the White Paper mainly refers in order to assure good governance: Openness, which primarily means active communication by the institutions as well as making governmental decisions more accessible and understandable.

Better information and transparency of EU policy-making shall be supplemented by improving consultation and dialogue not just with territorial and functional interests but also with civil society groups and individual citizens. A range of instruments is suggested and has been put into practice in the last few years: for instance, "the opening up of advisory committees to civil society, business test panels, and venues for ad hoc and on-line consultation" (Kohler-Kock, \& Rittberger, 2007a, p. 10). Thus, Openness in terms of improved transparency is, in fact, a prerequisite for public accountability, and openness in terms of better access to decision-making bodies is a pre-condition for political participation" (Rodriquez, 2008, p. 61).

The second important principle is the notion of Participation. This element is mainly ensured through wide involvement throughout the whole policy process; as it has been argued, the fundamental importance of this principle is that it "should help policy makers to stay in touch with European public opinion, and could guide them in identifying European projects which mobilise public support". Moreover, the role of the European civil society is viewed as support to representative democracy through the European Parliament, rather than as an alternative.

As the Commission put it: "the aim is for participatory democracy to be reconciled as much as possible with representative democracy in order to increase the acceptability and effectiveness of European decisions". In the following years, other statements about the necessity to enhance openness, transparency and participation have been launched; however a detailed analysis of these issues remains outside the scope of this book. ${ }^{25}$

24 Accountability entails that institutions and Member States explain their actions and take the necessary responsibility for such actions; Effectiveness requires that policies are effective and timely, with clear objectives, and evaluation of their future and past impact, and are pursued at the proper level and implemented in a proportionate way; Coherence necessitates that policies and actions cross the boundaries of sectorial policies, are performed with a clear view as to overall consistency and are more easily understood. See also Heldeweg, 2005, p. 3.

25 See the European Transparency Initiative" (ETI) November 2005. The Initiative is intended to "build on a series of transparency-related measures already put in place by the Commission, in particular those taken as part of the overall reforms being implemented since 1999 and in the White Paper on European Governance. Major achievements in this 
Nevertheless, what is crucial to summarise is that the suggestions made by the White Paper represent an innovative theoretical construction; also in practice, the mechanisms of deliberative and participatory democracy have remained rather "rudimentary" (Shaw, 2000, p. 382).

It is clear that the White Paper does not give the answer to all issues. However, in spite of its shortcomings it is, at least, a beginning; indeed, a trend towards democratisation through strengthening the role of the European citizen can be found since the Treaty of Maastricht up to the recent Lisbon Treaty. The participatory instruments introduced at the EU level to resolve the democratic deficit can be identified: firstly, access to information, secondly, public participation and finally, access to justice.

\subsubsection{Access to Environmental Information}

The call for more transparency and democratisation (Frost, 2003, p. 89) of the EU's decision-making process was met by the publication of a Commission paper on Openness in the Community, ${ }^{26}$ which in turn led to the Code of Conduct on access to documents, later implemented by two decisions: one by the Commission ${ }^{27}$ and another by the Council. ${ }^{28}$

Later, the Treaty of Amsterdam ${ }^{29}$ provided further steps to complete the regime on access to the Institutions' documents by inserting former Article 255 into the EC Treaty. This Article stated that "Any Union citizen and any natural or legal person residing or having a registered office in a member state, shall have a right of access to European Parliament, Council and Commission documents".

\footnotetext{
field are: a) the "access to documents" legislation, which provides the framework for access to the unpublished documents of the EU institutions and bodies through register of documents or following individual requests. b) the launch of databases providing information about consultative bodies and expert groups advising the Commission; c) wide consultation of stakeholders and in-depth impact assessments prior to legislative proposals; d) the Commission's "Code of Good Administrative Behaviors", which is its benchmark for quality service in its relations with the public. Moreover, the Commission adopted a new "Green Paper on a European Transparency Initiative" on May 3rd 2006.

The Commission emphasized, in particular, that 'inherent in the idea of partnership is consultation and participation'. By the same token, the Commission stressed the importance of a 'high level of transparency' to ensure that the Union is 'open to public scrutiny and accountable for its work'. Rodriquez, 2008, p. 61.

26 COM (93) 258 final, OJ C 166/5, 2 June 1993.

27 Decision 94/90, (1994) O] L 340/41.

28 Decision 93/371, (1993) O] L 340/43.

29 Treaty of Amsterdam, O] C 340 of 10.11.1997. The Treaty was signed on 2 October 1997 and entered into force on 1 May 1999.
} 
It further established that a new legally binding regime on access to documents should be implemented by May 2001. Indeed, as will be analysed in the following paragraph, legislation, namely the "Transparency Regulation", was adopted on May 30, 2001 and entered into force on December 3, 2001.30

Ex Article $255 \mathrm{EC}$, in granting this right, has given citizens increased protection. In fact, it is an explicit implementation and manifestation of Article 1 of the Treaty on the European Union when it states: "This Treaty marks a new stage in the process of creating an ever closer union among the peoples of Europe, in which decisions are taken as closely as possible to the citizen" (Schram, 2005, p. 24).

The Nice Treaty ${ }^{31}$ did not change anything further but moved on in the same direction and introduced a non-legally binding Charter of Fundamental Rights ${ }^{32}$ which establishes in its Article 42 that "Any citizen of the Union, and any natural or legal person residing or having its registered office in a Member State, has a right of access to the European Parliament, Council and Commission's documents" (De Abreu Ferreira, 2007b, p. 399).

The scope of both Article 42 and former 255 is narrow: first, it excludes noncitizens and non-resident natural or legal persons from the access to information, and secondly, existing commitments to transparency under former Article 255, in this first version of the provision, covered only the Commission, Council and European Parliament and not all European institutions and bodies (Kiss, 2008, p. 161).

\subsubsection{Public Participation in Environmental Matters}

\subsection{White Paper on European Governance}

Some steps have been made to increase participation as well, and important steps were taken through the measures used to implement the White Paper on European Governance, although with limited outcome (Heldeweg, 2005, p. 2). For instance, the Economic and Social Committee ${ }^{33}$ has successfully launched

30 Regulation (EC) $N^{\circ} 1049 / 2001$ of the European Parliament and of the Council of 30 May 2001 regarding public access to European Parliament, Council and Commission documents, O] L 145, 31.5.2001, p. 43, available at www.eur-lex.europa.eu/LexUriServ/ LexUriServ.douri=CELEX:32001R1049:EN:TML.

See Von Unger, 2007, p. 440.

31 Treaty of Nice, O] C 80, 10 March 2001. The Treaty was signed 26th February 2001 and entered into force on 1 February 2003.

32 Charter of Fundamental Rights of the EU, O] C 364/1, 18 December 2000. The Charter of Fundamental Rights is the result of a joint proclamation, by the Council, the European Parliament and the Commission at the Nice Council.

33 This role for EESC is recognised in former Article 257 EC which gives EESC the role of representing "the various economic and social components of organised civil society". "In 
different kinds of initiatives; it has pressed ahead with the opening up to a broader and mainly EU-level public audience, which serve both as platforms and contact points for advocacy networks (Kohler-Kock, 2007b, p. 260).

The Committee has introduced the instrument of online consultations as well. Thus, every proposal that is to be decided upon is made public, "every citizen and every organisation is invited to comment, every petition can be read online, and the Commission reports about the results at the end of the process" (KohlerKock, 2007b, p. 260). But unfortunately, those forums of consultation do not live up to the expectations of participative democracy and deliberative democracy. ${ }^{34}$ For instance the European Consultative Forum on the Environment and Sustainable Development (ECFESD) was scarcely consulted by the Commission and, during its first four years of existence, only on two occasions was able to reach out to the larger public (Kohler-Kock, 2007b, p. 255).

\subsection{Constitution for Europe and the Following Plan "D"}

The idea of the White Paper to give citizens a voice and to open civil dialogue influenced the development which followed it toward a participatory and deliberatory democracy in the EU Treaty. In particular, an important step in this direction could have been the inclusion of the principle of participation in the 2004 Treaty establishing a Constitution for Europe. ${ }^{35}$

Indeed the Constitutional Treaty in its first part 'the democratic life of the Union' contained a provision on representative democracy: "the functioning of

\footnotetext{
September 1999, EESC produced an own-initiative opinion on the role and contribution of civil society organisation in the building of Europe in advance of the First Convention of civil society organised at European level, arranged by EESC in October 1999. The 1999 Opinion is interesting in setting out a broad overview of the multiform, multidimensional and, to a more limited extent, multilevel nature of European civil society. Of particular interest are the attributes which the Opinion attaches to civil society in terms of its pluralism (the selforganisation of society into diverse social group), autonomy (the free-will of individuals to engage in social action, albeit framed by the wider constitutional framework of the state), solidarity (action in the common interest), public awareness (creation of a climate of social communication), participation (within and outside the political system)": Rodriquez, 2008, p. 67; Armstrong, 2002, p. 113.

34 For example the European Consultative Forum on the Environment and Sustainable Development (ECFESD): "even though its structures meet the demands for equal geographical and political representation, openness and transparency, it neither lived up to the standard of deliberation not did it bring about increased participation of interested actors". See Kohler-Kock, 2007b, p. 262.

35 Among the others, see Fossum, \& Menendez, 2005, p. 380; Barbi, 2005; Birkin-Shaw, 2004, p. 57; Cremona, 2003, p. 1347; Tizzano, 2003, p. 249; Kokott, \& Rüth, 2003, p. 1315; Closa, 2005, p. 145; Daswood, \& Johnston, 2004, p. 1481; Peters, 2004, p. 37; J. Bering Liisberg, 2010; Abromeit, \& Wolf, 2005.
} 
the Union shall be founded on representative democracy" (Article 1-45), ${ }^{36}$ and a provision on 'participatory democracy'(Article 1-46) which explicitly mentioned: "The Institutions shall, by appropriate means, give citizens and representative associations the opportunity to make known and publicly exchange their views in all areas of Union action" and Paragraph 2 affirms "The Institutions shall maintain an open, transparent and regular dialogue with representative associations and civil society". The adoption of the principle of participation was interpreted by scholars as a new effort to integrate the idea of direct and close cooperation between EU institutions and European civil society (Kohler-Kock, 2007b, p. 255).

Other important elements introduced by the European Constitution, were citizens' initiatives, which reflect the idea of deliberative democracy, as also held by the Lisbon Treaty, into the overall representative structure of the EU. ${ }^{37}$

This instrument was new for the EU democracy, but unfortunately very weak since the initiatives can only invite the Commission to consider it without a mandatory obligation to follow it, and they are also restricted to issues which are required for the purpose of implementing the constitution (Kohler-Kock, \& Rittberger, 2007a, p. 1). Moreover, as some commentators have pointed out, there is "a significant danger that political and economic elites (could) drive, if not manipulate the process, weakening rather than enhancing legitimacy" (Lee, 2005, p. 120).

Lee has underlined another weakness linked to the protection of minorities: "the minimum number of Member States whose citizens are involved in the initiative, and the number of citizens from each member state, need to be filled out by highly sensitive legislation. The difficulty is that the emergence of a European public for the purposes of participatory democracy is no more imminent than is a European public for the purposes of representative democracy" (Lee, 2005, p. 120). So, this norm only provides a limited contribution to moving beyond the democratic deficit.

36 See par. I: "The functioning of the Union shall be founded on representative democracy"; par. II: "Citizens are directly represented at Union level in the European Parliament. Member States are represented at Union level in the European Parliament. Member States are represented in the European Council by their Heads of State or Government and in the Council by their governments, themselves democratically accountable either to their national Parliaments, or to their citizens", and par. III: "Every citizen shall have the right to participate in the democratic life of the Union. Decisions shall be taken as openly and as closely as possible to the citizen".

37 See Peters, 2004, p. 37, in Article p. 44. The author considers the citizens' initiative laid down by Article 1-47, par. 4, as one of the few real novelties presented by the Treaty: "Independent of actual future resort to that instrument, the mere option might become an important symbol of genuine, bottom-up democracy. It seems apt to over- come the citizens' feeling of powerlessness vis-à-vis a gigantic European bureaucracy, while at the same time preserving the Commission's monopoly of legislative initiative". 
The persistence of the lack of power of European citizens and the increased gap between them and the EU was clearer after the negative French and Dutch referenda on the Constitutional Treaty. ${ }^{38}$ The Commission understood that more democratisation was necessary for the future of Europe and consequently the Member States embarked on a 'reflection period' about how to remedy the failed Constitutional Treaty. In 2005, Commissioner Margot Wallströ launched a new initiative called Plan " $D$ " as in Democracy, Dialogue and Debate. ${ }^{39}$

The Plan was about debate, dialogue and listening with the goal of stimulating a wide public debate and building a new consensus on the future direction of the European Union. Nevertheless, it is clear that the emphasis on dialogue and debate is not sufficient because, to be truly democratic and to help identification with the European project, "not only interest groups but also the citizens themselves should be encouraged to participate in genuine debates before final decisions are taken, although this is primarily a task for civil society organisations and political parties" (Parry, 2010).

Thus, in 2006 the White Paper on European Communication Policy ${ }^{40}$ tried to complete this approach by developing tools and initiatives for citizens' involvement. The Commission's "A citizens' agenda for Europe", adopted on 10 May $2006^{41}$ stressed the need to shift to a "policy agenda for citizens" drawing upon continued dialogue with the public via the implementation of Plan D (Barnard, 2007, p. 271).

The last step undertaken by the EU to improve participation was the Treaty of Lisbon which recognised the necessity to make the EU "more democratic, meeting the European citizens' expectations for high standards of accountability, openness, transparency and participation; more efficient and able to tackle today's global challenges such as climate change, security and sustainable development". 42

\subsection{Treaty of Lisbon}

The purpose of the Lisbon Treaty has been to simplify the institutional structure and the decision making process in order to increase efficiency, coherence and

38 Snyder, 2004, p. 255. See also Schwarze, 2006, p. 199. On the failure of the constitutional referenda in France and the Netherlands, see specifically Hurrelmann, 2007, p. 343. Recently, see also De Burca, 2006, p. 6; Joerges, 2006, p. 2. On the 'period of reflection' on the future of Europe after the failed referenda, see: Editorial, $2007 a, p .561$.

39 Available at www.speakupeurope.eu/plan_d.html.

40 Available at www.epri.org/epriknowledge/contents/Material_2nd_EPRI_workshop/ white_paper_en.pdf.

41 Available at www.eur-lex.europa.eu/LexUriServ/LexUriServ. do?uri=CELEX:52006DC0211:EN:NOT.

42 For more information see the website: www.europa.eu.int. 
democratic legitimacy. The Preamble establishes that the aim of the Treaty is: "to complete the process started by the Treaty of Amsterdam and by the Treaty of Nice with a view to enhancing the efficiency and democratic legitimacy of the Union and to improving the coherence of its action" (Clientearth, 2009).

The Treaty reconfirms the reliance on the Nation-State model of representative democracy, ${ }_{13}^{43}$ nevertheless it may be possible to identify some changes moving towards participatory and deliberatory democracy.

The first one is relative to the access to information: the Lisbon Treaty expands the number of institutions subject to transparency stating that "Any citizen of the Union [...] shall have a right of access to documents of the Union institutions, bodies, offices and agencies", Article 15(3), but does not do likewise concerning the subjects who possess the right.44 There are also exemptions, with the European Court of Justice, the European Central Bank and the European Investment Bank falling thereunder except where "exercising their administrative tasks" (Benson, \& Jordan, 2008, p. 280).

Another step towards more democratisation is the inclusion, or better the 'reinclusion' in the Treaty of Lisbon, of the participation principle. Indeed Article 11, like the Constitution before it, picks up on the 'democratic' possibilities of 'participation'. One of the striking differences between the Constitutional Treaty and the Lisbon Treaty is that the latter no longer mentions the concept of 'participatory democracy'.

Nevertheless, it includes exactly the same provisions which described 'participatory democracy' in the Constitutional Treaty: however, without a title. Some authors have criticised the disappearance of this concept from the text because it "illustrated the sensitivity around the question whether 'participatory democracy' should be a normative model for European governance" (Smismans, 2009). Other scholars have argued: "contrary to the constitutional Treaty (which) had "pompously" announced as the principle of participatory democracy in the Union, at minimum the Reform treaty is a bit more "honest": it does not boast about any principle, but only replaces the old paragraph 4 of 1-47, stating that there is a European citizens' initiative" (Pichler, \& Giese, 2008, p. 117).

However, also without an explicit mention, Article 11 calls on the participatory mechanisms of citizens' initiatives, establishing: "not less than one million

43 Article 8a refers to the principle of representative democracy, stating that "citizens are directly represented at Union level in the European Parliament. [...] Every citizen shall have the right to participate in the democratic life of the Union. Decisions shall be taken as openly and as closely as possible to the citizen.. Political parties at European level contribute to forming European political awareness and to expressing the will of citizens of the Union".

44 Indeed the right is granted only to the EU citizens. 
citizens who are nationals of a significant number of Member States may take the initiative of inviting the Commission, within the framework of its powers, to submit any appropriate proposal on matters where citizens consider that a legal act of the Union is required for the purpose of implementing the Treaties".

As under the Constitution, the details of this provision are to be filled out by legislation, and consequently Article 24 establishes that "the European Parliament and the Council, acting by means of regulations in accordance with the ordinary legislative procedure, shall adopt the provisions for the procedures and conditions required for a citizens' initiative within the meaning of Article 11 of the Treaty on European Union, including the minimum number of Member States from which such citizens must come". The European Parliament has already indicated some criteria for its implementation arguing that any initiative should be admissible if it concerns EU competence and if it is not contrary to the general principles of the Treaty, and it should not take more than two months to decide on its admissibility.

Apart from such citizens' participation, the new Treaty allows the participation of representative associations: "The institutions shall, by appropriate means, give citizens and representative associations the opportunity to make known and publicly exchange their views in all areas of Union action. The institutions shall maintain an open, transparent and regular dialogue with representative associations and civil society" (Holtz, 2008).

\subsubsection{Access to Justice: Former Article 230}

Access to justice is an important instrument of participation because its role is to protect the other two rights. As will be examined in detail in the following, the Lisbon Treaty has amended access to justice, with a new paragraph 4 in Article 263 (formerly 230): "Any natural or legal person may, under the conditions laid down in the first and second paragraphs, institute proceedings against an act addressed to that person or which is of direct and individual concern to them, and against a regulatory act which is of direct concern to them and does not entail implementing measures".

Before this amendment, a person or business could only challenge the legality of certain EU acts directly before the Court, if it could be shown that the act was of "direct and individual concern" to that person or business. The Court has been heavily criticised for interpreting the notion of 'individual concern' in a strict manner; in fact, in other respects the EC] has applied teleological interpretations of Article 230. Thus, the strict standing rule in Article 230(4) EC has not been so much due to its wording, as due to its strict interpretation (Ballesteros, \& Luk, 2010). The only way of opening the doors for these individuals and ensuring their right to effective judicial protection at an EU level was to amend the EU Treaty. 
Thus, there is no longer any requirement for "individual concern" in respect to a "regulatory act" which "does not entail implementing measures" (Lee, 2008, p. 135). This can cover certain regulations which previously were almost impossible to challenge. Individuals may challenge the legality of those acts if they can show 'direct concern'.

Already in 1995 the EC] suggested that the Member States should change the wording in Article 230(4) EC and introduce more liberal standing rules. ${ }^{45}$ This suggestion was not followed in the Nice Treaty. The EC] interpreted that position as a signal not to liberalise Article 230(4). Only with the Treaty Establishing a Constitution for Europe, and then the Treaty of Lisbon, the Member States decided to follow the EC] suggestion.

The impact of the change proposed in the Lisbon Treaty is not measurable at the moment since there is no clarity on what kind of a regulatory act at an EU level is within the framework of the new hierarchy of acts. In fact, the wording "regulatory act" is not mentioned anywhere else in the Treaty, and survived from the Constitution; but the Lisbon Treaty does not pick up on the Constitution's recategorisation of EU laws and procedures into legislative acts and non-legislative acts. The doctrine has already suggested that this term refers to a normative act of general application, as opposed to an administrative act of individual scope (Pallemaerts, 2009, p. 30).

Nevertheless, the extent to which standing is relaxed depends on the judicial interpretation of this phrase (Lee, 2008, p. 1, 3, 5). As a matter of fact, as shall be discussed below, the main obstacle to accessing justice in order to challenge acts of Community Institutions which contravene EU Environmental Law is not "direct" but "individual" concern. The reforms of the standing requirements of Article 230(4), which result from the Lisbon Treaty, do not constitute a major step forward. At any rate it only applies to a limited sub-category of acts of Community Institutions (Pallemaerts, 2009, p. 30).

Moreover, in the same provision, the Treaty maintains the requirement that an act (other than regulatory acts) adopted by EU Institutions has to be of direct and individual concern for it to be challenged by a natural or legal person. These requirements have been interpreted to exclude environmental NGOs from having access to the EC] (Ballesteros, \& Luk, 2010). The issues concerning this Article are very complex and they will be explored in detail in the following discussion.

45 Report of the EC] of Justice on Certain Aspects of the Application of the Treaty on European Union, Luxembourg, May 1995. 


\section{2. "Environment" in the European Community}

To discuss Environmental Democracy from a European perspective, it is necessary to call for a synopsis of the relationship between Europe and environmental protection. Thus, this part briefly sets out the historical evolution of the "ecologisation" (McGillivray, \& Holder, 2001, p. 139) of European governance in order to provide a background for the subsequent parts. Nevertheless, before starting it is necessary to analyse the term environment in the EU context.

\subsubsection{The Definition of the Term "Environment" in Europe}

Currently, what is considered as "European environment" is not clear since there is not a conclusive and uniform definition of environment in EU law. The environment is defined differently depending on the context and instrument in which it is being used (Kiss, \& Shelton, 1993, p. 4). ${ }^{46}$ The diverging definitions can be categorised into wide and narrow definitions and Environment may also have an anthropocentric or ecocentric character. The following overview shall first address the term "natural resources" particularly since they constitute part of both sets of definitions and second, an overview of the debate surrounding the definition shall be given. ${ }^{47}$

In the European context natural occurrences are listed as natural resources which are not human or man-made. According to several directives and regulations

\footnotetext{
46 See also Thornton, \& Beckwith, 2004, p. 5.

47 Despite the vagueness of the term Environment, it is possible to find two categories of definitions: one includes only natural elements, a narrow definition, and one includes also a social dimension, a wide definition. The following shall give an overview over that. First, however, the term natural resources shall be addressed particularly since they constitute part of both sets of definitions.

One can categorise the definitions of natural resources on the international level into two sets (Reiners, 2009). It has been suggested that natural resources are naturally occurring materials that are useful to man (Skinner, 1986, p. 1). Another proposal is that natural resources are tangibles or intangibles which may be used in an economic manner or to create economic value and which are not manufactured or produced (Rosenne, 1986, p. 63). These definitions imply that the appearance in nature must have an economic value. This economically-valuing definition represents the first set of definitions.

The second category covers definitions of natural resources, which do not include an economic element (This approach is favoured by Schrijver, 1995, pp. 15-16. It was suggested that natural resources are all physical natural goods, as opposed to those made by man (Cano, 1975, p. 1). Hence, there are basically two sets of definitions, one requiring an economic value, the other one not. Nevertheless, both definitions agree on the fact that a natural resource is something nature given so to speak and not man-made. Moreover, they do not seem to include human beings.
} 
natural resources comprise fauna and flora, natural habitats, groundwater ${ }^{48}$ and surface waters, ${ }^{49}$ soil, ${ }^{50}$ oil, natural gas and solid fuels. ${ }^{51}$ Sometimes their economic value is stressed, ${ }^{52}$ but also elements without an economic value fall within the definition. Moreover, the EU is a party to the Convention on Biological Diversity ${ }^{53}$ since $1993^{54}$ and Article 2 of the Convention lists as natural resources air, water, land, flora and fauna and natural ecosystems. ${ }^{55}$

48 E.g. Step 1(j) of Annex I to the Directive 2009/31/EC of the European Parliament and of the Council of 23 April 2009 on the Geological Storage of Carbon Dioxide and Amending Council Directive 85/337/EEC, European Parliament and Council Directives 2000/60/EC, 2001/80/EC, 2004/35/EC, 2006/12/EC, 2008/1/EC and Regulation (EC) No 1013/2006, O] 2009, L 140/114.

49 E.g. Groundwater and surface waters Preambular 28 of Directive 2000/60/EC of the European Parliament and of the Council of 23 October 2000 Establishing a Framework for Community Action in the Field of Water Policy, OJ 2000, L 327/1; fresh water Article 2(2) (g) of Regulation (EC) No 1638/2006 of the European Parliament and of the Council of 24 October 2006 Laying Down General Provisions Establishing a European Neighbourhood and Partnership Instrument, OJ 2006, L 310/1; water in general Preambular 12 of Commission Regulation (EC) No 889/2008 of 5 September 2008 Laying Down Detailed Rules for the Implementation of Council Regulation (EC) No 834/2007 on Organic production and Labelling of Organic Products with regard to Organic Production, Labelling and Control, O] 2008, L 250/1; Article 13(1) of Regulation (EC) No 1905/2006 of the European Parliament and of the Council of 18 December 2006 Establishing a Financing Instrument for Development Cooperation, O] 2006, L 378/41.

50 E.g. Preambular 12 of Commission Regulation (EC) No 889/2008 of 5 September 2008 Laying Down Detailed Rules for the Implementation of Council Regulation (EC) No $834 / 2007$ on Organic production and Labeling of Organic Products with Regard to Organic Production, Labeling and Control, O] 2008, L 250/1.

51 E.g. all three Preambular 2 of Directive 2003/30/EC of the European Parliament and of the Council of 8 May 2003 on the Promotion of the use of Biofuels or other Renewable Fuels for Transport, O] 2003, L 123/42; Preambular 2 of Directive 2002/91/EC of the European Parliament and of the Council of 16 December 2002 On the Energy Performance of Buildings, O] 2003, L 1/65; only oil Preambular 1 of Directive 2009/33/EC of the European Parliament and of the Council of 23 April 2009 on the Promotion of Clean and Energy-Efficient Road Transport Vehicles, O] 2009, L 120/5.

52 E.g. Preambular 5 of Council Directive 1999/13/EC of 11 March 1999 on the Limitation of Emissions of Volatile Organic Compounds Due to the Use of Organic Solvents in Certain Activities and Installations, OJ 1999, L 85/1.

53 Convention on Biological Diversity of 5 June 1992, 1760 UNTS, p. 79.

54 See available at www.cbd.int/countries/?country=eur.

55 See further on these examples not mentioning the term natural resource explicitly but describing the natural environmental elements, not human and not man-made Article 2(1)(c)Council Directive 67/548/EEC of 27 June 1967 on the Approximation of Laws, Regulations and Administrative Provisions Relating to the Classification, Packaging and Labelling of Dangerous Substances, OJ 1967, L 196/1 Article 2(12) of Council Directive 91/414/EEC of 15 July 1991 Concerning the Placing of Plant Protection Products on the Market, OJ 1991, L 230/1. 
Hence, at the European level natural resources are also nature given occurrences which are not man-made and do not include human beings. Furthermore, they have numerous appearances that include air, water, land, flora and fauna, natural ecosystems, oil, gas and fossil fuels.

\subsubsection{Wide Definition of "Environment"}

Some definitions of the environment found at the European level are wide. A wide definition is one which comprises not only natural resources but, in addition, humans or man-made things or even both. ${ }^{56}$

The "Declaration on the Environment" adopted by the Heads of State and Government in 1990, at the defining of Treaty negotiations which led to the adoption of the Treaty of Maastricht is interesting. The Declaration lists numerous elements: a "clean and healthy environment: the quality of air, lakes, coastal and marine waters, the quality of food and drinking water, protection against noise, protection against contamination of soil, soil erosion and desertification, preservation of habitats, flora and fauna, landscape and other elements of the natural heritage, and the amenity and quality of residential areas".

The concept of the environment is an all-encompassing term including economic, social and aesthetic elements, including the preservation of natural and archaeological heritage and the man-made as well as the natural environment (Krämer, 2003b). This notion can be considered to be evolving and open to development in the face of new discoveries, technical advances and greater societal interest in, and understanding of, the subject matter (Comte, 2006, p. 190).

No explicit legal definition of the environment is found in the Treaty of the European Communities. However, former Article 174(1) and former Article 175(2) of the EU Treaty ${ }^{57}$ imply that the European environment comprises natural resources such as the natural element water, man-made elements such as waste and human beings themselves (Thornton, 8 Beckwith, 2004, p. 4).

Thus, the EU Treaty seems to give a broad definition of the environment. Another example of a European document implying a broad definition is the Helsinki Final Act of $1975 . .^{58}$ There the co-operation in the environmental field comprises air, water, land and soil, genetic resources, rare animal and plant

56 A definition of an ordinary dictionary for instance defines the environment as the circumstances, objects or conditions, by which somebody or something is surrounded, (ed.) Allen, 2000, p. 465.

57 OJ 2006, C-321 E/39.

58 Conference on Security and Co-Operation in Europe Final Act of 1 August 1975, 14 ILM 1992, p. 1292. 
species, natural ecological systems, human health and waste. ${ }^{59}$ Still a broad definition, although slightly narrower, is the definition contained in the Lugano Convention of 1993.60

Its Article 2(10) defines the environment as comprising "natural resources both abiotic and biotic, such as air, water, soil, fauna and flora and the interaction between the same factors, property which forms part of the cultural heritage; and the characteristic aspects of the landscape".

This definition does not include humans, but natural resources and man-made elements (Thornton, \& Beckwith, 2004, p. 5). Moreover, it also comprehends the relationships between the elements. Other definitions that comprise also the relationship between the environmental elements are enshrined in Directives, though excluding man-made things. ${ }^{61}$ In particular, Article 2(1)(a) of Directive 2003/4/EC ${ }^{62}$ which implements the Aarhus Convention comprises as environmental elements air, atmosphere, water, soil, land, landscape, natural sites, biological diversity and its components, including genetically modified organisms, and the interaction among these elements. Several Directives do not provide for a definition of the environment, but list for example humans and the environment next to one another and thereby imply at least that the environment does not comprise humans but might include man-made things. ${ }^{63}$

59 Conference on Security and Co-Operation in Europe Final Act of 1 August 1975, pp. 28-29.

60 Convention on Civil Liability for Damage Resulting from Activities Dangerous to the Environment, Lugano Convention of 21 June 1993, ETS 150.

61 Listing "water, air and land and their inter-relationships as well as between them and any living organism" Article 2(1)(c)Council Directive 67/548/EEC of 27 June 1967 on the Approximation of Laws, Regulations and Administrative Provisions Relating to the Classification, Packaging and Labeling of Dangerous Substances, OJ 1967, L 196/1; Article 2(12) of Council Directive 91/414/EEC of 15 July 1991 Concerning the Placing of Plant Protection Products on the Market, O] 1991, L 230/1; another example for a wider definition not including man-made things is to define the environment to be the natural surroundings of or the complex of external factors that acts upon an organism, an ecological community, or plant and animal life in general, Allen, 2000, p. 465.

62 Directive 2003/4/EC of the European Parliament and of the Council of 28 January 2003 on Public Access to Environmental Information and Repealing Council Directive 90/313/EEC, O] 2003, L 41/26.

63 Preambular 6 of Directive 1999/45/EC of the European Parliament and of the Council of 31 May 1999 Concerning the Approximation of the Laws, Regulations and Administrative Provisions of the Member States Relating to the Classification, Packaging and Labelling of Dangerous Preparations, O] 1999, L 200/1; Article 1 of Council Directive 1999/32/EC of 26 April 1999 Relating to a Reduction in the Sulphur Content of Certain Liquid Fuels and Amending Directive 93/12/EEC, O] 1999, L 121/13; Article 1 of Directive 2001/18/EC of the European Parliament and of the Council of 12 March 2001 on the Deliberate Release into the Environment of Genetically Modified Organisms and Repealing Council Directive 90/220/EEC, O] 2001, L 106/1; Article 6(5) of Directive 2000/76/EC of 
Hence, several documents at the European level provide a wide definition of the environment which seems to include natural resources and sometimes human beings, man-made things or all of the above.

\subsubsection{Narrow Definition of "Environment"}

Some of the definitions of the environment found at the European level are narrow, however. A narrow definition will only include natural resources but exclude man-made things and human beings.

For the European Environment Agency, ${ }^{64}$ which periodically assesses the state of the European environment, the definition of the European environment in these reports is a cluster of environmental issues, such as quality of air, water and soil. Of course this approach is limited and narrow because it takes into account only the indicators and not the complexity of this concept.

Examples of definitions representing a narrow approach are less frequent. Other examples of a narrow definition are found in the Habitats Directive of 1992 which only comprises habitats and wild fauna and flora ${ }^{65}$ and the Wild Birds Directive of 1979 which only comprises wild birds. ${ }^{66} \mathrm{~A}$ narrow definition is also found in several other directives. Again, they do not expressly define the environment but from listing the environment next to man-made things, humans or other elements it can at least be concluded what the environment does not comprise. For instance, some directives list humans and animals and the environment. ${ }^{67}$ They, hence, seem to exclude humans and animals from the

the European Parliament and of the Council of 4 December 2000 on the Incineration of Waste, O] 2000, L 332/91; Article 1(7) of Commission Directive 2001/59/EC of 6 August 2001 Adapting to Technical Progress for the 28th time Council Directive 67/548/EEC on the Approximation of the Laws, Regulations and Administrative Provisions Relating to the Classification, Packaging and Labelling of Dangerous Substances, O] 2001, L 225/1; Article 4(2) of Council Directive 2002/55/EC of 13 June 2002 on the Marketing of Vegetable Seed, O] 2002, L 193/33; Article 1(a) of Directive 2009/41/EC of the European Parliament and of The Council of 6 May 2009 on the Contained Use of Genetically Modified MicroOrganisms, O] 2009, L 125/75; Article 1(1) of Directive 2008/50/EC of the European Parliament and of The Council of 21 May 2008 On Ambient Air Quality and Cleaner Air for Europe, O] 2008, L 152/1.

64 See for example EEA: Environment in the European Union at the Turn of the Century, Copenhagen 1999.

65 Preambular 1 of Council Directive 92/43/EEC of 21 May 1992 on the Conservation of Natural Habitats and of Wild Fauna and Flora Official Journal 1992, L 206/7.

66 Council Directive 79/409/EEC of 2 April 1979 on the Conservation of Wild Birds Official Journal 1979, L 103/1.

67 Article 2(1)(b) of Directive 98/8/EC of the European Parliament and of the Council of 16 February 1998 Concerning the Placing of Biocidal Products on the market, O] 1998, L 123 / 1; Preambular 6 Directive 2000/16/EC of the European Parliament and the Council 
ambit of the environment. Even though the definitions only including natural resources are narrower than the ones above, their importance is not to be underestimated especially due to the above-shown wide range of occurrences falling under the term natural resources.

Thus, the narrow definitions that only comprise natural resources also have a wide scope of application. It is also possible to identify several definitions at the European level. For example, a text of the Council of the European Community includes "water, air and land and their inter-relationship as well as relationships between them and any living organism". 68

The term "environment" could be said to cover "all those elements which in their complex inter-relationships form the framework, setting and living conditions for mankind, by their very existence of by virtue of their impact" ${ }^{\prime \prime} 9$

The EU Treaty indicates, without expressly interpreting the term, in conformity with former Article 174 (1) and (2), that the shape of the environment extends to human beings, natural resources, land use, town and country planning, waste and water. Thus, in principle this includes almost all areas of the environment, in particular fauna and flora and climate. The inclusion of town and country planning underlines the fact that the environment includes man-made as well as natural elements. ${ }^{70}$

of 10 April 2000 amending Council Directive 79/373/EEC on the Marketing of Compound Feedingstuffs and Council Directive 96/25/EC on the Circulation of Feed Materials, O] 2000, L 105/36; Article 6 of Directive 2002/32/EC of the European Parliament and of the Council of 7 May 2002 on Undesirable Substances in Animal Feed, O] 2002, L 140/10

68 Council Directive of June 27, 1967, 1967 O.J.; See: Kiss, \& Shelton, 2000.

69 EEC, OJ C 115, May 1976, p. 2. See also: Larsson, 1999, p. 121.

70 Thornton, \& Beckwith, 2004, p. 1. Other definitions that encompass the link between the environmental elements are provided in Directives which keep out man-made things. Listing "water, air and land and their inter-relationships as well as between them and any living organism" Article 2(1)(c)Council Directive 67/548/EEC of 27 June 1967 on the Approximation of Laws, Regulations and Administrative Provisions Relating to the Classification, Packaging and Labeling of Dangerous Substances, OJ 1967, L 196/1; Article 2 (12) of Council Directive 91/414/EEC of 15 July 1991 Concerning the Placing of Plant Protection Products on the Market, OJ 1991, L 230/1; another example for a wider definition not including man-made things is to define the environment to be the natural surroundings of or the complex of external factors that acts upon an organism, an ecological community, or plant and animal life in general, Allen, 2000, p. 465. In particular, Article 2(1)(a) of Directive 2003/4/EC (Directive 2003/4/EC of the European Parliament And Of The Council of 28 January 2003 On Public Access to Environmental Information and Repealing Council Directive 90/313/EEC, O] 2003, L 41/26) which implements the Aarhus Convention comprises as environmental elements air, atmosphere, water, soil, land, landscape, natural sites, biological diversity and its components, including genetically modified organisms, and the interaction among these elements. 


\subsubsection{Anthropocentric and Ecocentric Character of Environment in Europe}

The Environment mainly has an anthropocentric character in Europe, so that the focus is on protecting the health of humans rather than protecting the environment for its own sake (Parola, 2013). This can be seen for instance in the Habitats Directive, in which the destruction of a habitat for development is provided for, so long as certain procedural requirements are fulfilled. The anthropocentric orientation of EU environmental law and its practical expression in legal instruments implicitly reject ecological thought. ${ }^{71}$

Nevertheless, this strong statement should be moderated, because on several occasions the EU has led action in certain fields which entail a more ecocentric and global approach.

An example can be found concerning the Animal welfare which was introduced in a Protocol annexed to the TEC by the Amsterdam Treaty.

The Lisbon Treaty has amended the existing wording of the Protocol and added the amended Treaty (Article 13). The changes brought by the Treaty to the existing text include references to fisheries, technological development and space policies, and in particular, the classification of animals as "sentient beings". Recognising "animals as sentient" is symbolically important and may also have potential legal and policy implications. Both EU institutions and Member States "consequently have to pay full regard to animal welfare in formulating and implementing policy in these sectors" (Benson, \& Jordan, 2008, p. 283).72

Another important example is the action in the fight against Climate Change which demonstrates how the EU also pursues ecological objectives. During the negotiation of the Constitutional Treaty, Climate Change was not such a "hot topic" (Lee, 2008, p. 133) but it has become a new objective in the Lisbon Treaty. This adds proof to the EU's awareness of that topic as a "global environmental problem", which has to be resorted to at the global level; but reaffirms that concrete action has to be undertaken also at regional and national levels.

This Article can be linked also to the new provisions relating to "Energy policy" (Corazza. 2009) as contained in the new Article 194. The reasons for the link are: firstly, scientific and technological advance and the aim to "promote energy efficiency and energy saving and the development of new and renewable forms

\footnotetext{
71 McGillivray, \& Holder, 2001, p. 143.

Ecocentric approach which originally comes from the first and ancestral relations between Nature and man and which is still present in some religious and philosophical views around the world, gives a different concept to the "Environment", one in which all organic existence in a single framework is united in harmonious interaction: Parola, 2013. 72 See also Camm, \& Bowles, 2000, p. 195.
} 
of energy", and secondly, because all of the objectives of energy policy should be pursued "with regard for the need to preserve and improve the environment" (Lee, 2008, p. 131).

In addition, it is interesting to note that the EC] places huge importance on the relationship between environmental quality and human health; but also numerous decisions in which the Court in a situation of conflict between natural resources and other interests decided in favour of the environment exist, following an ecocentric approach. For example, Lappel Bank outlined that the Wild Birds Directive accords special protection to species which constitute "a common heritage of the Community". ${ }^{73}$ Moreover, in two landmark decisions the Court explicitly ruled that environmental legislation designed to protect human health and the environment should be interpreted as creating rights and obligations for individuals vis-à-vis the environment. ${ }^{74}$

Thus, it should be underlined that, in particular, regarding the legislation on the protection of animals and habitats, this ecocentric approach has largely been ensured over the last twenty-five years through the jurisprudence of the $\mathrm{EC}]^{75}$ which "fine-tuned the rather rudimental provisions of EU legislation, generally trying to protect the environment against the greed of administrations or economic operators" (Krämer, 2009, p. 195).

In conclusion, the approach to the environment by Community Law is in principle anthropocentric; however, some grains of the ecocentric approach have entered into EU environmental law provisions, in particular by ECJ jurisprudence.

\subsubsection{Protection of Environment in the Treaty}

The Treaty of Rome, which in 1957 created what was then the European Economic Community, did not contain any reference to the environment. At that time, the main scope of such Treaties was to establish functionally integrated markets in order to attain economic benefits. ${ }^{76}$

73 Case C- 44/95, R. v. Secretary of State for the Environment, (1996) ECH I-3805.

74 Case C-361/88, Commission v. Germany [1991] ECR I- 256; Commission v. Germany [1991] ECR I-825,7. see Jans, 1996; Ward, 2000, p. 137.

75 See for instance: ECJ Case 272/80, Biologische Produketen (1981) ECR 3277; Case 412/85, Commission v. Germany (1987) ECR 3503; Case C-322/86, Commission v. Italy (1988) ECR I-3995; Case C-355/90, Commission v. Spain (1993) ECR I-4221; Case C365/97, Commission v. Italy (1997) ECR I-7773.

76 Indeed the original aim of the EEC was one of economic integration rather than protection of human rights or the environment. The legal regime of the European Union operates within three pillars. The first pillar, established by the Treaty of Rome (with subsequent amendments) organizes the European Community and addresses the economic objectives of the Community as well as social and environmental issues. The 
Nevertheless, with the forceful support of the European Court of Justice starting decades ago, environmental protection has been elevated from a "position of neglect" to one of the "essential objectives" of the European Union. ${ }^{77}$ In fact, it became clear that the creation of a common market and the development of economic growth could not be achieved without a policy for the environment and without an environmentally friendly orientation.

The first official mention of environmental protection came in a declaration made in October 1972 where the Heads of the Member States clearly expressed the political will to protect the environment: "Economic expansion is not an end in itself: its firm aim should be to enable disparities in living conditions to be reduced. It should result in an improvement in the quality of life as well as in standards of living. As befits the genius of Europe, particular attention will be given to intangible values and to protecting the environment, so that progress may really be put at the service of mankind". ${ }^{78}$

This was followed by the First Action Programme on the Environment in 1973. ${ }^{79}$ Since then, five further Action Programmes have been produced and the

second pillar is the Common Foreign and Security Policy established under the Treaty of the European Union from 1992 (Maastricht Treaty). The third pillar addresses police and judicial cooperation in criminal matters. See EUROPA, The E.U. at a glance, Treaties and Law, available at www.europa.eu/abc/treaties/index_en.htm.

77 Which the relevant directive 'must be seen in the perspective of', $A D B H U$, Case $240 / 83$ para. 13 . We see here the use of the general goals of the EU in the interpretation of secondary legislation. See inter alia Jacobs, 2006, p. 185; Sjafjell, 2009.

78 See E.C. Commission, 6th General Report (1972) p. 8: see also Shelton, 1993, p. 557.

79 There have been six such programmes since 1973, the first four converging periods of four or five years. 1st Environmental Action Programme, 1973-1976 (1973) O] C112; 2st Environmental Action Programme, 1977-1981 (1977) OJ C 139; 3st Environmental Action Programme, 1982-1986 (1981) O] C46; 4st Environmental Action Programme, 1987-1992 (1987) OJ C328; 5st Environmental Action Programme 1993-2001 (1993) O] C138; 6st Environmental Action Programme, 2002-2012 (2002) O] L242/1. See BurnettHall, \& Jones, 2009, p.14.

The 1st Action Programme set out 11 "Principle of a Community Environmental Policy" that continued to be supported in subsequent Programmes. These may be summarised as follows: (1) Pollution should be prevented at source rather than dealt with after the event; (2) Environmental issues must be taken into account at the earliest possible stage in planning and other technical decision making processes; (3) Abusive exploitation of natural resources is to be avoided; (4) the standard of knowledge in the EC should be improved to promote effective action for environmental conservation and improvement; (5) the polluter should pay for preventing and eliminating nuisances, subject to limited exceptions and transitional arrangements; (6) Activities in one country should not degrade the environment of another; (7) The EC and the Member States must in their environment policies have regard to the interests of developing countries and should aim to prevent or minimise any adverse effects on their economic development; (8) There should be a clearly defined long-term European environmental policy that includes participation in international organisations and co-operation at both regional and international levels; (9) Environmental protection is a matter for everyone in the EC, at all levels; their co- 
current Sixth Programme extends from 2002-2012 (Pedersen, 2010). The first Programme made the attempt to articulate a single environment policy for the EEC and it establishes two main principles still in use, the Polluter Pays Principle and the Preventive Action Principle (Collins, 2006, p. 98).

The awareness vis-à-vis the environment, as it will be seen, has been reflected gradually also in the Treaties. In fact, environmental protection was promoted to the level of the main objectives provisions of the EU Treaty by the Treaty of Maastricht, while the Amsterdam Treaty recognised environmental protection as an independent goal, 'rather than an incidental requirement of economic growth (Craig, \& De Burca, 2008, p. 21).

Since then environmental protection has been a central issue in the EU, and so many huge steps on environmental regulations and policies have been made that the EU has been considered a largely successful experiment in regional environmental governance since the EU is "one of the world's most advanced examples of international cooperation' in the realm of environment and beyond". 80

\subsubsection{Single European Act}

Although, until 1986, there was not an explicit Treaty basis for environmental action, with the fundamental support of the EC] the Commission and Council

operation, and the harnessing of social forces, is necessary for success. Education should ensure the whole community accepts its responsibilities for future generations; (10) Appropriate action levels must be established -local, regional, optional Community and international - for each type of pollution and area to be protected; (11) Major aspects of national environmental protection policies should be harmonised. Economic growth should not be view for purely quantities aspects.

80 In addition to leading by example, the EU has also intentionally undertaken the project of actively promoting sustainable development and environmental protection at the international level, through such mechanisms as capacity building in developing countries, the conclusion of multilateral environmental treaties, and other forms of international diplomacy. See generally Commission Communication External Action of 16 February 2006, Thematic Programme for Environment and Sustainable Management of Natural Resources including Energy, $\operatorname{COM}(2006)$ 20, available at eur-lex.europa. eu/LexUriServ/ site/en/com/2006/com2006_0070en01.pdf. See also: Collins, 2007b, pp. 323-324; Smith, 2002, p. 241. "The EU has accorded preeminent importance to environmental protection, EU environmental law and policy has grown exponentially, and Europe has become an acknowledged world leader in sustainable development and also now in climate change politically, the EU has seen itself as a leader in this area. Climate change is perceived as an issue with great popular resonance, where the EU wishes to be seen to provide something obviously valuable beyond what the Member States can provide". See Somsen, 2002. 
used former Article 100 (ex 94) and former 235 (ex 308) as a legal basis to develop a body of environmental legislation. ${ }^{81}$

The first Article provides for the approximation of Member State laws that directly affect the establishment or functioning of the common market and was the principal instrument for environmental regulation; former Article 235 provides for action necessary to attain, in the course of the operation of the common market, one of the objectives of the Community, where the Treaty itself has not provided for the necessary powers. This approach to environmental policy is explained by the idea that during that period this policy was instrumental to the market (McGillivray, \& Holder, 2001, p. 139).

The protection of the environment was settled by an autonomous Community action: the Single European Act (SEA) of 1986, by which three new Articles (Articles 130r, 130 s and 130t) setting out the basic principles of Community action on the environment, were introduced. The SEA codified the status quo on decision-making in the environmental arena by providing an explicit legal base for environmental protection.

The fundamental principles which control Community environmental policy are: firstly, a principle of incorporation, according to which the policy of the Community in every field of its competence must be shaped after the assessment of the requirements for the protection of the environment.

Secondly, there is the principle of subsidiarity ${ }^{82}$ which, and in combination with, the possibility of the Member States to depart from the Community rules and regulations, gives "precedence to national legislation over community law of the environment and hinder(s) the latter's development to a full legislative system with harmonised and homogenous application throughout the EU" (Karakostras, 2008, p. 12).

The provisions offered not just a legal basis for the enforcement of measures by Community institutions, but they also included the fundamental principles which control their acts. These principles do not have the character of a guideline or of a general declaration of intent, but are fully legally binding. In other words, the acts of the Community institutions and of the Member States must be in compliance with them.

The environmental provisions inserted in the EU Treaty through the SEA have since been renumbered and amended by the Maastricht, Amsterdam and Nice Treaties (Pedersen, 2010). After the Maastricht Treaty, the Community ceased to

81 Case 92/79 Commission v. Italy (1980) EC] 1115; Case 240/83 Procureur de la République v. Association de défense des Bruleurs d'huiles Usagées (1983) ECR 531.

82 A detailed discussion of the nature and scope of this principle is beyond the scope of the book. However in this topic, among others, Macrory, 1999, p. 363; Toth, 1992, p. 239; more recently, see Estella De Noriega, 2002. 
have an economic-only orientation and was transformed into a multidimensional institution with wider powers to interfere with the legal orders of the Member States also in the environmental field.

This treaty enlarged, improved and integrated, for the first time explicitly, environmental protection in the principles and objectives of the Community in Articles 2 and 3 of the EU Treaty. The amended former Article 130 of the SEA elevated the Community's environmental action to Community policy. In other words, environmental protection is not just a component of other Community policies, but it "must be integrated into the definition and implementation of the other Community policies". Moreover, it is explicitly provided that the competent institutions for the implementation of Community environmental policy should aim at a high level of protection.

\subsubsection{The Treaty of Amsterdam}

The few changes brought by the Treaty of Amsterdam were in agreement with the proposal to broaden the Community activities for the environment. Here for the first time environmental protection is elevated to a Community objective independent of economic development and growth and it is established as a general imperative that permeates the whole range of Community Action (Karakostras, 2008, p. 15). Indeed, Article 2 of the Treaty of Amsterdam "sets forth the objectives of the Union, including those of achieving balanced and sustainable development, strengthening the protection of the rights and interests of the EU nationals and maintaining and developing the Union as an area of freedom, security and justice".

Thus, the Treaty of Amsterdam has altered the objectives of the Community, making the promotion of the core environmental concept of "sustainable development" a central objective in the revised Treaty. What is important for the current purpose is that such a principle includes an inter- and intra-generational element, e.g. the main idea of the responsibilities vis-à-vis future generations; this will be dealt with below. The inclusion of the mentioned principle has also been seen "as a response to the Member States adopting sustainable development as a guiding principle in national legislation and policy documents, thereby discharging their obligations under international law" (McGillivray, \& Holder, 2001, p. 148).

Finally, the Treaty introduced the environmental policy Integration Principle. This commitment was implemented by the Cardiff Process, launched by the heads of government in 1998, and it also underpins the Sixth Environmental Action Programme (Benson, \& Jordan, 2008, p. 283).

Hence, the principle of integration is reinforced with its codification in Article 6 , which states that environmental protection requirements must be integrated 
into the definition and implication of Community policies and activities referred to in Article 3, in particular with a view to promoting sustainable development.

Former Article 174 determines the objectives that Community policies on the environment shall pursue, and it reaffirms that such policies shall aim at a high level of protection taking into account the diversity of situations in the various regions of the Community, listing the principles on which it shall be based (Kiss, 2008, p. 166).

\subsubsection{The Constitution for Europe}

The Constitution for Europe (Beyer, Coffey, Klasing, \& Homeyer, 2004, p. 218) and the following Treaty of Lisbon did not have a prominent "green agenda", nevertheless some provisions could be interpreted in an environmental light and they could even have a big impact in the environmental field. In this context, the most important provision of the Constitution is Article 1-47, which provided for participative democracy by ensuring the right of public participation and citizens' initiatives.

It is interesting to note that as of June 2007, the 18 European Citizens Initiatives that have been launched ${ }^{83}$ have enjoyed great popularity on the home-pages and the online signature forms. Eleven of the sixteen were proposed by NGOs including well-known organisations like Greenpeace and Friends of the Earth. Unfortunately, none have been launched by individuals (Fischer, \& Lichtblau, 2008, p. 333). The topic of the initiatives concerned different issues: EU-organisation/political process, economics, health care/social issues and environment protection, in particular addressing the problems related to nuclear power and genetic food.

The most important and interesting for this study was the initiative " 1 million Europeans against Nuclear Power", supported by numerous NGOs which joined the initiative at different points in time. During the course of the constitutional debate in 2003, several smaller antinuclear organisations, like Atomstopp, became aware of the possibility of the European Citizens Initiatives.

Consequently, at a French anti-nuclear demonstration in January 2004, the decision was made to make use of this new instrument as a political means for the struggle against nuclear energy, and the internet was selected as the main medium of communication.

In July 2005, Friends of the Earth and other smaller NGOs decided to support the initiative. Unfortunately, only 634,686 Europeans have signed against nuclear energy. The campaign failed principally for two reasons. Firstly, due

83 Available at www.citizens-initiative.eu. 
to considerable problems in the procedure: in fact, each organisation has a different deadline for decisions. Secondly, other campaigns already have top priority, such as climate change, which has become a popular topic, and so the topic of nuclear power is losing attraction for NGOs. ${ }^{84}$

\subsubsection{The Lisbon Treaty}

The Lisbon Treaty largely maintains the status quo in its explicit environmental provisions. Nevertheless, it has been said that the Treaty has introduced "some limited", but "potentially broad ranging modifications to the environmental "rules of the game" in the EU" (Benson, \& Jordan, 2008, p. 280).

The principles and objectives of environmental policy remain "virtually" the same (Lee, 2008, p. 131). Indeed, the provisions containing environmental content have not changed the terminology of the objective concerning environmental protection, namely that of achieving "a high level of protection and improvement of the quality of the environment" (Article 3(3) TEU). Then, the Lisbon Treaty includes the environmental provisions in former Articles 174 to 176 of the TEC establishing the legal basis for environmental legislation in Articles 191 to 193 of the TFEU. However, the environmental title in the treaty has been amended to specifically include the aim of combating climate change as one of the EC's objectives. ${ }^{85}$

Article 191 of the TFEU presents the objectives of the Union policy on environment stating that: "Union policy on the environment shall contribute to pursuit of the following objectives: preserving, protecting and improving the quality of the environment; protecting human health; prudent and rational utilisation of natural resources; promoting measures at international level to deal with regional or worldwide environmental problems, and in particular combating climate change" (Clientearth, 2009).

Concerning Sustainable Development, the Treaty introduces a new definition which is based closely on the wording of the Constitution and which amends former Article 2 of the TEU ${ }^{86}$ (now Article 3 of the TEU). The sentence added that

84 Available at www.million-against-nuclear.net/. See also Lorenz, 2007; Egger, 2007.

85 The Art. 191(1) TFEU as amended, (formerly 174(1)) now states: "Union policy on the environment shall contribute to pursuit of the following objectives: - preserving, protecting and improving the quality of the environment, - protecting human health, prudent and rational utilisation of natural resources, - promoting measures at international level to deal with regional or with regional or worldwide environmental problems, and in particular combating climate change".

86 The Union shall establish an internal market. It shall work for the sustainable development of Europe based on balanced economic growth and price stability, a highly competitive social market economy, aiming at full employment and social progress, and 
to "promote scientific and technological advance" has to be read in accordance with the principle of Sustainable Development. This means that scientific and technological advances have to promote ${ }^{87}$ Sustainable Development, identified as being achievable through meeting several new goals related to aspects of the internal market, ${ }^{88}$ including raising living standards and the quality of life.

Moreover, amongst other core objectives of the EU, Article 3 also establishes that the Union shall in its dealings with the wider world "contribute to peace, security and the sustainable development of the Earth. Finally the pursuit of Sustainable Development would become a specific policy goal in the external relations of the $E U^{\prime \prime}$.

Some changes in the Lisbon Treaty are not so explicit, but they have considerable potential to affect the future development of environmental regulation. An example is Article 11 concerning citizen initiative, which has already been examined. It should be said that for environmental purposes this instrument is welcomed, although there is a risk of manipulation by the elites, and of deepening divisions between different parts of the Union, ${ }^{89}$ and there are many elements that need to be clarified.

The Treaty talks about "a million signatures" without specifying whether it requires signatures to come from a minimum number of countries or a minimum number per country involved, or the requirements for their collection, verification and authentication. It also does not define the meaning of the Commission being "invited" to make a proposal. Is it obliged to draw up a proposal or is it only invited to consider it? The Commission has prepared a Green paper where it proposes answers to these questions, recognising the Commission's responsibility to present conclusions and propose measures accordingly (Clientearth, 2009).

Among the implicit changes, there is also an amendment of Article 6: the new EU Charter of fundamental rights, signed 12 December 2007, become by

\footnotetext{
a high level of protection and improvement of the quality of the environment. It shall promote scientific and technological advance.

87 Sustainable development is also an element of Article 3(5) on external matters: "In its relations with the wider world, the Union shall uphold and promote its values and interests and contribute to the protection of its citizens. It shall contribute to peace, security, the sustainable development of the Earth, solidarity and mutual respect among peoples, free and fair trade, eradication of poverty and the protection of human rights, in particular the rights of the child, as well as to the strict observance and the development of international law, including respect for the principles of the United Nations Charter". Lee, 2008, p. 133.

88 For instance, "price stability", "highly competitive social market economy and "full complement".

89 "At this level, participation is likely to be restricted to organised pan-European interest groups; the contribution of 'participation' to 'democracy' in any familiar sense is by no means automatic". See Lee, 2008, p. 131.
} 
reference binding in the same way as the treaty. ${ }^{\circ 0}$ Secondly, the European Union shall accede to the European Convention on Human Rights. ${ }^{91}$

Concerning the first novelty, the Charter, through the Lisbon Treaty, would become a legally binding instrument ${ }^{92}$ in particular its Article 37, under Title IV Solidarity, which states that "a high level of environmental protection and the improvement of the quality of the environment must be integrated into the policies of the Union and ensured in accordance with the principle of sustainable development".

This wording of the Article reflects and combines the provisions already present in the environmental chapter of the TEC and the TFEU. ${ }^{93}$ The exact boundaries of the interpretation of this Article will have to be set by case-law. Nevertheless, as will be deal with below, the inclusion of the principle of a high level of environmental protection, per se, does not give citizens 'a right' to a clean environment or the right to claim positive action in courts by the EU Institutions or Member States. ${ }^{94}$

Regarding the European Convention on Human Rights, ${ }^{95}$ after a long discussion over the possibility of accession, finally with the entering into the force of the Lisbon Treaty the EU has become a party to the Convention..$^{96}$ Accession to the

90 Charter of Fundamental Rights of the European Union, Dec. 14, 2007, 1007 O.J. (C 303) 1. The Charter represents a mixture of civil, political as well as economic, social, and cultural rights. See Butler, \& De Schutter, 2008, p. 277.

91 Relating to the binding character of the Charter, it has to be noticed that England and Poland have opted out. See Protocol on the application of the charter of fundamental rights of the European Union to Poland and to the United Kingdom.

92 However, concerning the binding character of the Charter, it has to be noticed that England and Poland have opt-outs. See: Protocol on the application of the Charter of Fundamental rights of the European Union to Poland and to the United Kingdom. Available at www.eur-lex.europa.eu/LexUriServ/LexUriServ.do?uri=OJ:C:2007:306:0156:0157:EN:PDF. The reason England negotiated this, was to avoid major changes in their labour law; Poland was mostly concerned about but the possible equal treatment of homosexual and heterosexual couples. See Hectors, 2008, p. 165.

93 Indeed, Article 191 (2) requires the Union policy on environment to aim at a high level of protection. However the Charter Article is broader since it covers all Union policies.

94 How ONGs have suggested that provision "serve as a basis for a demand of a judicial review of legislative acts/omissions in cases where the EU Institutions or Member States would have manifestly breached their margin of discretion". See Clientearth, 2009.

95 The European Convention on Human Rights (ECHR) is an international treaty which was signed on 4 November 1950 in Rome under the auspices of the Council of Europe. It sets out a number of fundamental rights. To date, 47 countries across the European continent have ratified this convention, including all $27 \mathrm{EU}$ countries. Available at www. lawsociety.org.uk/documents/downloads/guide_to_treaty_of_lisbon.pdf\#17.

96 The long discussion over how to effectively protect fundamental rights in the EU had, inevitably, led to the consideration of a possible accession by the EU to the ECHR, as a way of creating an "international supplementary constitution" of the EU or, as the EC], 
European Convention Human Rights means that the EU and its institutions will be accountable to the European Court of Human Rights for issues concerning the Convention. In other words, the EU institutions would be directly subject to the Convention and to the jurisprudence of European Courts which would be able to directly apply the Convention as part of EU law. Nevertheless, the Treaty of Lisbon and its Protocols state that accession to the Convention will not affect the EU's competences and that provision will be made for preserving the specific characteristics of the EU and EU law.

In conclusion, it may be said that through the explicit and implicit environmental provisions in the Treaty, the institutions of the EU have generated a vast amount of legislation relating to the environment.

put it in Rutili (EC], Case C-36/75, Roland Rutili v. Ministre de l'Intérieur, 28 October 1975. (Uerpmann-Wittzack, 2006) a source of "guidelines which should be followed within the framework of Community Law". But this possibility of an accession by the EU to the ECHR was for long time expressly ruled out by the EC] in its (Opinion 2/94) and by the Treaties. 


\section{Environmental Democracy in Europe}

"In Europe, as much as everywhere, humankind depends on Earth's ecosystems for the services they provide -for resources such as food, water, timber, fibre and fuel; for functions such as climate regulation, the absorption of wastes and the detoxification of pollution; and for protection as afforded by the atmospheric ozone layer". ${ }^{97}$

The intention here is not to repeat the Environmental Democracy structure theorised in my previous book, but to try to identify what EU law is doing with these concepts (Parola, 2013). Hence, it is now useful to observe, following the above presented overview of the scope of the terms "democracy" and "environment" at the European level, how those two aspects may be unified in the concept of Environmental Democracy.

\subsection{Dimensions of European Environmental Democracy: Form and Space}

\subsubsection{Form}

The first point to analyse is which form of democracy can be found at the EU level and if, implicitly or explicitly, it can be used to achieve environmental goals. To sum up this point through the outcomes emerging from above, it can be said that the representative form is the base of the EU, but a general movement towards a participatory and deliberatory democracy has been made in the last twenty years.

Features reflecting more participatory elements at the EU level can be found in ex-Articles 255 and 263 of the Treaty and in Articles 41 and 42 of the Charter of Nice, concerning access to information and access to justice. Also, the participation element has been recognised by the Lisbon Treaty when it introduced the novel instrument of a citizens' initiative. Thus the new Treaty recognised, even if merely in a small part, the model and mechanisms of "deliberative democracy".

97 EUROPEAN ENVIRONMENT AGENCY: The European Environment - State and Outlook 2005, Copenhagen, at p. 28. 
Nevertheless, several points in this last element of the deliberative and participatory democracy are missing. Indeed, direct democracy in Europe is and remains "the eternal Cinderella" (Editorial, 2007b, p. 353). In fact, in the new TEU, as it has already been underlined, the measure to participate has been criticised (Allegri, 2008) ${ }^{98}$ by most scholars mainly because the Article on citizens' initiative is too poor and weak, since it is principally based on dialogue and consultation and "doesn't include 'strong' participatory powers for citizens, like the right to promote referendums, to form European political parties, or other forms of participation" (Valvo, 2004, p. 27).

Also concerning these rights it is not even clear who the primary beneficiaries are, representative associations or civil society? What is clear, however, is that participation is meant by the Treaties as a "collective rather than individual opportunity". ${ }^{99}$ Moreover, another obscure point is paragraph 4 of Article 11 which does not clarify whether European citizens "will be able to predetermine in detail the contents of proposals they will invite the Commission to submit, or if the definition of such contents will be up to the Commission itself" (Villani, 2005, p. 643). Further it has been argued that one million people are only 0,25\% of the European population, which is "light years away" from a democratic majority (Pichler, 2008, p. 32).

The above measures are, of course, enough to satisfy the citizens' criticism of a lack of democracy or the lack of elements of participatory and deliberative democracy. The vagueness of the tools to participate has been interpreted as a sign, firstly "of mistrust of the European people or even as a sign of its inconsistency: in both cases future perspectives of European democracy look gloomy" (Allegri, 2008, p. 2), and then as a sign that the leaders of the Union's representative democracy "did not want to meet their citizens too much" (Pichler, 2008, p. 32).

From a more explicitly environmental point of view, despite this generally negative judgement concerning the tools to introduce the elements of participatory democracy at the EU level, it is possible to note a major "enthusiasm" towards the recall possibility to transform the EU into an environmental participatory democracy. Although the movement towards environmental participatory democracy does not appear in the Treaty provisions yet, it may

98 Although Europe is still constituted in a representative way, it should finally get involved with direct democracy "and not only simply playing around with it a bit". Pichler \& Giese (2008): "Proposition for a European Initiative procedure-Incentives of founding Art. 8b (4) Treaty of Lisbon".

99 Although art 24 rules that every citizen has the right to petition the European Parliament, to apply to the Ombudsman, and to write to any of the institutions, bodies, offices or agencies of the Union in one of the official languages, receiving an answer in the same language. 
be found in secondary legislative instruments, in a number of directives, in the signature of the Aarhus Convention, as well as in the directives and regulations which the EU has adopted to implement that Convention. Moreover, environmental rights and ecological duties have found a more or less important place in the EU system as well.

In conclusion it is possible to underline that, as will be discussed in detail in the following parts, there is a general movement towards an environmental participatory democracy in Europe rather than a general participatory or deliberatory democracy and this movement is amplified by the granting of environmental rights and duties to the European citizens.

\subsubsection{Space}

The second dimension is the spatial one. The spatial context of Europe, of course, is the territory of Europe. In the previous book, I wrote that Environmental Democracy has to be built at different levels, global and local, and the EU also recognises this as a way to try to resolve the environmental crisis (Parola, 2013). Indeed, the First Environmental Action Programme referred to five possible levels of action - global, local, international, regional and national - and the need "to establish the level best suited to the type of pollution and to the geographical zone to be protected". Thus, the EU acknowledges that the efficiency and effective action to protect the environment can be supported at different levels following the principle of Subsidiarity. ${ }^{100}$

Of course the initial insertion of this principle was to prevent an undesirable extension of Community competences but from an environmental point of view it can be used in the above approach: the environmental global problem needs a global or international action and local problems need local action, which can be divided again into regional and national problems and their corresponding solutions.

So in the context of the Environment the principle of Subsidiarity, introduced by the Single European Act, stipulates that environmental action should be

100 Principle of Subsidiarity "which has its most recent historical origins in the teachings of the Roman Catholic Church, but which is also to be found in political thought of the eighteenth and nineteenth century and can be traced back to earlier times, and which finds a more complete modern day expression in German Basic Law, declares that no action should be taken by a larger political entity unless its objectives cannot be effectively achieved by action of a smaller" political entity. See Emiliou, 1992, p. 383; Cross, 1995, p. 107. 
taken at the Community level to the extent to which environmental objectives could be attained better at that level than at the Member States level. ${ }^{101}$

Another aspect of the spatial dimension is that at the regional level there are different problems which can be resolved just at this level, through collaboration and coordination between the States which compose this region.

For instance, the Water Framework Directive ${ }^{102}$ is based first on the recognition of the local environmental problems, as the recitals also remind us: "In Europe depletion of the water resource has been a continuous process for forty years. Human water uses have increased all over the period, without any consideration of sources initially imagined as self-purifying". ${ }^{103}$ Secondly, this local problem can be solved by "developing an integrated Community policy on water". ${ }^{104}$

Moreover, the success of this Directive "relies on close cooperation and coherent action at Community, Member State and local level as well as on information, consultation and involvement of the public, including users". ${ }^{105}$ Furthermore, recital 18 goes on to affirm the fundamental importance of solving the problem at different levels within the Community: "Community water policy requires a transparent, effective and coherent legislative framework. The Community should provide common principles and the overall framework for action. This Directive should provide for such a framework and coordinate and integrate, and, in a longer perspective, further develop the overall principles and structures for protection and sustainable use of water in the Community in accordance with the principles of subsidiarity".

The objective of this directive is "maintaining and improving the aquatic environment in the Community". ${ }^{106}$ In order to achieve this goal, recital 23 makes it clear that: "Common principles are needed in order to coordinate Member States' efforts to improve the protection of Community waters in terms of quantity and quality, to promote sustainable water use, to contribute to the control of transboundary water problems, to protect aquatic ecosystems, and terrestrial ecosystems and wetlands directly depending on them, and to safeguard and develop the potential uses of Community waters".

101 Article130 r (4) before it was amended by the Amsterdam Treaty.

102 Directive 2000/60/EC establishing a framework for Community action in the field of water policy as amended by Decision 2455/2001/EC and Directive 2008/32/EC. See in general about WFD: Aubin, \& Varone, 2002, p. 28; Boscheck, 2006, p. 268; Bouleaul, 2008, p. 1747; Kaika, \& Page, 2003, p. 314; Kaika, 2003, p. 303; Ker Rault, \& Jeffrey, 2008, p. 241; Kostas Bithas, 2008; Moss, 2008; Naddeo, Zarra, \& Belgiorno, 2007, p. 243; Peuhkuri, 2006; Rodriguez, 2006.

103 Recital 4 of the WFD.

104 Recital 9 of the WFD.

105 Recital 14 of the WFD.

106 Recital 19 of the WFD. 


\subsection{Actors of Environmental Democracy at a European Level: the Role for European citizens}

This part assesses the development of norms which concern environmental rights and ecological duties within the context of the development of EU environmental law.

Before starting with the discussion on rights and duties, a word must be said about the importance of the role of European citizens vis-à-vis the protection of the environment. ${ }^{107}$

The recognition of the fundamental role of European citizens in the environmental field is clear in the EU environmental protection system. An example is the Sixth Environment Action Program namely "Our Future our Choice: An Action Programme for the Environment in Europe at the Beginning of the 21st Century". This title is significant because it emphasises the importance of the environmental choice of the single European citizen.

Thus, this Programme proposes five priority "avenues" of strategic action to "help us meet our environmental objectives". ${ }^{108}$ For this book, a significant element of the programme is the fourth point entitled "Empowering Citizens and Changing Behaviour". This document mainly recognises that "in recent years we have begun to play a more active role, as individuals, in environmental protection. Many people have started to make efforts to change their personal and family behaviour, for example, by recycling, buying environment-friendly products and installing energy efficient systems in our households".

Then, the Action programme underlines that "well-informed citizens who are actively involved in environmental decision-making are a powerful new force in achieving environmental results". Moreover, practical information about the environment and which actions may protect or damage the environment, are fundamental since it helps people to choose and, for instance, buy alternative products and services that are energy efficient. Moreover, the Action Programme reminds us that more and more citizens are demanding a stronger voice in the decisions made at the community, regional, national and international level

107 Chalmers, 1999. On European citizenship, see also, recently, Besson, \& Utzinger, 2007, p. 573; Jacobs, 2007, p. 591; Kostakopoulos, 2007, p. 623; Magnette, 2007, p. 664.

108 The first is to improve the implementation of existing legislation. The second aims at integrating environmental concerns into the decisions taken under other policies. The third focuses on finding new ways of working closer with the market via businesses and consumers. The fourth involves empowering people as private citizens and helping them to change behaviour. Finally, the fifth aims at encouraging better land-use planning and management decisions. 
that affect our health and the quality of our environment. To be effective they "need quality information that they can use and understand and they need the appropriate access to decision-makers to be able to express their views". ${ }^{109}$ Thus, the interpretation of the EU approach is quite clear at least at a theoretical level, and the fundamental step to achieve this goal is to provide instruments to push the people to feel like environmental and ecological citizens by granting them environmental rights and duties.

To exercise those rights and respect those duties they need to know and understand what the environmental issues are, what is needed to resolve them and how they can contribute. Thus, environmental education, information including indicators and maps, and awareness raising initiatives will be essential to this process. Those tools, hence, ought to aim at encouraging more sustainable lifestyles.

Besides, the efforts to develop this new role at a European level "have often been driven by the need for greater enforcement of existing EC environmental law" (McGillivray, \& Holder, 2001, p. 163). On several occasions, the Communication mentions that citizens are often the first to discover breaches of Community environmental laws. ${ }^{110}$

Indeed, individuals and NGOs also play an important role in providing information so that the Commission can properly fulfil its watchdog function, and the bulk of former Article 226 EC cases are initiated by following up private complaints. ${ }^{111}$ For example, the last report ${ }^{112}$ shows that the majority of cases were initiated by following up private complaints, and only a minority of these were pursued on the basis of the Commission's own investigations. ${ }^{113}$

109 "Public participation in planning could be improved through more easily accessible and better quality information. Environmental reporting by companies and authorities needs to make information available at a local level so that people can easily obtain data on emissions from factories or other installations in their area". See the text of Sixth Environmental Action Program.

110 Commission Communication on Implementing European Community Environmental Law, COM (2008) 773 final, 18 November 2008, p. 6, Commission Communication on Implementing European Community Environmental Law, COM (2008) 773 final, 18 November 2008, p. 6.

111 Available at www.ec.europa.eu/community_law/infringements/pdf/25_ annexes_1_to_4_en.pdf.

$11225^{\text {th }}$ Annual Report on monitoring the application of Community law [COM(2008) 777].

113 Moreover the environmental sector generates by far the highest number of complaints and represented 43 per cent of the active complaints. Of course it has to be noted that apart from the most obvious breaches such as illegal landfill or acts against protected habitats or species, ordinary "citizens are not able to detect less visible infringements, such as excess emissions of invisible gas, discharges into water courses above permit limits, or a failure to install best available pollution control techniques. They 
Thus, the question is now whether the important role played by individuals and recognised by the EU can transform the European citizenry into environmental and ecological citizens and whether this transformation will be similarly reflected in procedural and judicial rights and duties.

On 1 January 1993, as a result of the Maastricht amendments to the European Treaties, all nationals of Member States acquired under the Treaty something called citizenship of the European Union. ${ }^{114}$ The concept of citizenship is clearly stated in the Treaty and involves a number of individual rights, including the right to move and reside freely, and the right to vote or stand as a candidate in municipal elections in the country in which he or she is residing.

Although citizenship at the EU level is mainly constructed for the purpose of free movement and equal treatment, nevertheless a new approach, which incorporates an environmental dimension, has begun to be constructed. As a matter of fact, a movement to grant environmental rights and duties has been emerging for more than five years in secondary law, although, as will be discussed in the following, at the Treaty level there is no explicit recognition yet.

\subsubsection{European Environmental Rights}

This part will attempt to give a general framework under which it may be seen whether environmental rights are granted in the European Union's legal order and whether there is any implementation of the rights approach of Environmental Democracy (Hayward, 2000, p. 164-165). At present, a substantive human right to the environment does not exist explicitly in European law, as in international law (Parola, 2013). Nevertheless, the focus for this part is on the question of whether the existing EU environmental and human rights provisions already provide implicitly the protection of the right to an adequate environment.

Then, this part will seek to identify the main environmental procedural rights currently enjoyed by European citizens within the EU, and to assess whether these are such as to render unnecessary the provision of a fundamental substantive right to an adequate environment, entrenched or binding at the constitutional level of the EU.

The following discussion will take into account the different provisions from the Treaty, the European Charter of fundamental rights and the European

generally lack resources such as analytical laboratories, and access to facility premises. The Commission cannot rely primarily on private citizens to detect and report infringements of Community environmental law. The Commission should be able to develop its own strategy for monitoring the implementation of legislative measures falling outside citizen's awareness". Ballesteros, 2009, p. 54.

114 Article 8 of Treaty Establishing the European Community. 
Convention on Human Rights. The main reason concerning the analysis of the last two documents is that they have become very important since the Lisbon Treaty was signed and entered into force.

\subsubsection{Substantive Environmental Rights}

The Treaty in its present form does not provide any legal expression of a substantive environmental right. This does not mean that there were not some efforts to acknowledge this right. Indeed, since the late 1990s the institutions of the EU have started to discuss the necessity of such recognition. For instance, in preparations for an Intergovernmental conference, both the European Commission and a number of Nordic countries tried to promote the idea that EC law should contain an express inclusion of a right to a healthy environment or some similar right. ${ }^{115}$

Other proof of such efforts can be found in two statements of the Parliamentary Assembly of the Council of Europe, the first in November, 1999: "in the light of changing living conditions and growing recognition of the importance of environmental issues, it considers that the [European] Convention [on Human Rights] could include the right to a healthy and viable environment as a basic human right" 116 and recommended investigating the feasibility of amending the Convention to include such a right. ${ }^{117}$

Then the second declaration is a recommendation from 27 June 2003 , 1614 (2003) on Environment and Human Rights: "The Assembly recommends that the Governments of Member States: ensure appropriate protection of the life, health, family and private life, physical integrity and private property of persons in accordance with Articles 2, 3 and 8 of the European Convention on Human Rights and by Article 1 of its Additional Protocol, by also taking particular account of the need for environmental protection; recognise a human right to a healthy, viable and decent environment which includes the objective obligation for states to protect the environment, in national laws, preferably at constitutional level; safeguard the individual procedural rights to access to information, public participation

115 The 1994 Rapport of European Parliament's Committee on Institutional Affairs proposed a model constitution for the European Union which included a title on Human rights Guaranteed by the Union. There rights included, inter alias, "Everyone shall have the right to the protection and preservation of his natural environment". Doc EN/ RR/244/244403 27 January 1994. Macrory, 1996, p. 219.

116 Council of Europe, Standing Committee acting on behalf of P.A., 4 November, 1999, Texts Adopted, Recommendation 1431, online: Parliamentary Assembly <assembly.coe. int//Main.asp?link=http:// assembly.coe.int/Documents/AdoptedText/TA99/EREC1431. $\mathrm{HTM}>$.

117 See Shelton (1997) citing Jacque, (1997) p. 70-71. 
in decision making and access to justice in environmental matters set out in the Aarhus Convention".118

Despite the above mentioned expressions of awareness about the extreme importance of recognising a substantive right to environment, the EU has not yet explicitly enshrined it within the Treaty establishing the European Community (Shelton, 2001, p. 185). The only provision which could at least implicitly grant such a right is Article 37 of the Charter of Fundamental Rights of the European Union (Collins, 2007a, p. 143).

Nevertheless, there is a complex debate concerning the value and the interpretation to give to this provision. Thus, the question that will be at the centre of the following part is whether Article 37 contains a right to healthy environmental protection or whether it is rather a non-binding guiding principle. And, even more, if its legal significance has changed after the entry into force of the Lisbon Treaty which has declared the binding character of the Charter.

\subsection{Article 37 Codifies an Environmental Human Right}

Article 37 proclaims " $A$ high level of environmental protection and the improvement of the quality of the environment must be integrated into the policies of the Union and assured in accordance with the principle of Sustainable Development".

Some scholars have argued that this Article provides some "codification" of a right to environment. They point out the explanation given by the draft which says "the principle set out in this Article has been based on Article 2, 6 and 174 of the EC Treaty, which have now been replaced by Articles III-3(3), III-4 and III-129 of the Constitution. It also draws on the protection of some national constitutions".

This second part is the most important for the above interpretation. Most national Constitutions of the EU-27, hence, enshrine environmental protection as a fundamental right; therefore they grant to the Charter provision the status of a "formal" fundamental right (De Abreu Ferreira, 2007a).

The location in the national Constitution as well as the wording is varied; some appear under the heads of economic and social policy, while others under titles on fundamental rights, basic rights or individual rights. Concerning the wording, some of them proclaim it in a direct form as an individual right, ${ }^{119}$

118 See Council of Europe, P.A., 24th sitting, Texts Adopted, Recommendation 1614 (2003), online: Parliamentary Assembly<assembly.coe.int/Main.asp?link=/Documents/ AdoptedText/ta03/EREC1614.htm>. No "hard law" instruments have codified the connection, but again, this is unnecessary since we are dealing here with rights that are already enshrined in existing Conventions.

119 For instance the Constitution of Belgium, where the right to "lead a worthy life of human dignity" includes "the right to protection of a sound environment"(art. 23(3)(4)) See Martens, 2007, p. 287; Spain where the Article 45 (Spain) Constitution states that "everyone has the right to enjoy an environment suitable for the development of the 
while some constitutions oblige the state to protect the environment. ${ }^{120}$ It has been underlined that the last obligation might have the same meaning as the recognition of an individual right "since the concerned persons can ask the State authorities to respect it" (Kiss, 2008, p. 167).

Several European countries have not explicitly recognised a substantive right to environment within their Constitutions, but some of the Constitutional Courts of these same countries interpreted their Constitutions as including the right ${ }^{121}$ to protection of the environment" (Kiss, 2008, p. 167).

So according to those authors, Article 37 grants an implicit substantive right to the environment by the Constitutions of Member States; in other words, the legal ground of Article 37 is the national provision which recognises this right. Consequently the Article establishes a substantive environmental right.

Following, instead, the interpretation of another part of the doctrine, Article 37 has to be read in light of Article1 of the Aarhus Convention which, signed by the EU, affirms a substantive right to a healthy environment (Ermacora, 2003). On the grounds of this provision, binding for the EU, a general human right to a clean environment is acknowledged on the EU level, also including procedural rights (Jendroska, 2006, p. 66).

Following this interpretation, an attempt to express a more concrete formulation of this right was made by the Avosetta Group during the negotiation

person as well as the duty to preserve it."; Portugal where the Constitution asserts that "all have the right to a healthy ecologically balanced human environment and the duty to defend it" (CONSTITUIÇÃO DA REPÚBLICA PORTUGUESA [Constitution] Article 66 (Port.); Further north, the Finnish Constitution, adopted in 2000, states that the "public authorities shall endeavour to guarantee for everyone the right to a healthy environment".(Article 20 (Fin.), Article 20 stems from a constitutional reform taking place in the mid 1990s in Finland aiming at providing a more "coherent set of fundamental rights" in Finland. See Davies, 2007, p. 190). Likewise, the Norwegian Constitution, altered in 1992, contains a right to "an environment that is conducive to health". GRUNNLOV [Constitution] Article $110 B$ (Nor.). Most recently, France joined the ranks of European nations possessing constitutional guarantees of the right to environment in February of 2005. The French Constitution was amended in 2005 and now includes a Charter of the Environment ("Charter"). The Charter affords all citizens of France the right to live in a "balanced environment, favourable to human health". In addition, a great number of Eastern European countries have altered or changed their constitutions to include a substantive right to the environment: Czech Republic, Estonia, Hungary, and Slovenia. For example, the Hungarian Constitution states, "Hungary recognizes and implements everyone's right to a healthy environment". Article18 (Hung.), see also Bandi, 1993, p. 43. In doctrine See: Kiss, 2008, p. 167; Pedersen, 2010.

120 Greece (Article 24(1), the Netherlands (Article 21), Sweden (Article 2(2), Germany (Article 20 (a) and 31) and Austria (Comprehensive Constitutional Law on Environmental Protection Article1) See: Kiss, 2008, p. 167.

121 An example is Italy the right to health recognised by the Constitution has been interpreted by the Constitutional Court: Article 9(2) and 32(1) interpreted by the Constitutional Court inter alia in a judgment, n. 5172 on 6 October 1976. See Kiss, 2008, p. 167. 
of the Constitutional Treaty in 2003:122 "Everyone has the right to a clean natural environment. This right is subject to reasons of overriding public interest. It includes the right to participation in decision-making, the right of access to the courts and the right to information in environmental matters. A high level of environmental protection and the improvement of the quality of the environment must be integrated into the policy of the Union and ensured in accordance with the principle of sustainable development" (Ermacora, 2003, p. 29).123

\subsection{Article 37 Does Not Codify an Environmental Human Right}

Despite the above-mentioned scholars affirming that a substantive right already exists, most scholars deny this approach for the following reasons:

Article 37 has been defined by Kiss as the "poor parents" of the Charter, because it is drafted in a way that fundamentally differs from other parts of the Charter and its contents have "little in common with the other Articles" (Kiss, 2008, p. 161). This provision does not confer an individual right on the citizens and several points prove this interpretation.

Firstly, the right is placed in the Charter's Title IV on solidarity and not in Title V on individual rights. Indeed, the expressions used in the Charter to grant human rights and freedoms have different terms compared to the terms used in Article 37: for example, Article 2(1) provides "everybody has the right or the freedom" or Article 9 "the right [...] shall be guaranteed"; or concerning, for example, human dignity in Article10 (2) which stipulates "the right is recognised"; Article 34(2) says "Everybody [...] is entitled". Concerning the protection of the environment none of these terms has been used.

Other evidence may be found in the literal reading of the wording of the provision, in fact when it says "A high level of environmental protection [...] must

\footnotetext{
122 See Conference Report, 2003, p. 34.

123 This Avosetta idea took the suggestion from the proposal suggested by the Green G8: "The inclusion of environmental rights in the Charter of Fundamental Rights (to the Treaty)". Brussels (April 29, 2002) - The eight largest environmental NGOs in Europe, the "Green G8", have presented their initial contribution to the debate on the Future of Europe to the European Convention. The document, "The Future of the European Union, Environment and Sustainable Development", which is expected to be the first of a number of contributions towards the Convention, raised 12 issues for consideration by the Convention. For current purposes the significant issues are: "Include environmental rights in the Charter of Fundamental Rights. If the Charter is imported into the Treaty, the environmental Article must be amended to be phrased in terms of a right, as existing in several national constitutions and the Aarhus Convention. In no event, should existing Treaty Articles be replaced or modified by the Charter's provisions on environment as they stand now".

Available at www.eeb.org/press/2002/Green_G8_on_Convention_29_04_02.pdf.
} 
be integrated into the policies of the Union" the language demonstrates there is a clear obligation to achieve a high level of protection and not a right. ${ }^{124}$

Moreover, the Charter refers to environmental protection as a policy goal and not a right. ${ }^{125}$ In this light, Article 37 seems to add little in terms of a substantive right and appears to merely confirm the objectives of the Community, as set out in the EC Treaty. In fact, it appears just as a reinforcement of former Article 174(1) Treaty (Macdonald, 2008, p. 213). Thus, it is not a right for the citizens but just Union policy, as the title of the Article also indicates: "Environmental protection" and not right (Kiss, 2008, p. 161).

The question could be why a Charter of Fundamental Rights speaks about policies. And why did they not want to proclaim such a right? Probably the EU did not want to go so far, because of the difficulty in the definition of this right (Parola, 2013). ${ }^{126}$ So the EU's choice to classify it as a pure policy principle without legal content allowed them to find a way out of the aforementioned questions.

Nevertheless, according to some authors the definition problem is not a convincing reason not to act more in practice, because a "certain extent of vagueness is common to each human right". ${ }^{127}$ Although the above exposed points reduce the weight of Article 37, nevertheless it is possible to affirm that the Charter represents at least a little progress since it recognised the impossibility of ignoring the question of protection of the environment (Lee, 2008, p. 131). The debate stems from the common feeling of the fundamental need in Europe and in the World that a clean environment is necessary for the enjoyment of basic human rights.

In conclusion, the following question shall be answered: if Article 37 does not install a right to a healthy environment, how can a way be found to integrate a right to environmental protection available for each individual? A solution to fill

124 As Collins has well noted "Interestingly, the ambiguity as to the rights aspect of this provision would presumably allow courts to adopt either an anthropocentric or an eco-centric approach, since the provision does not specify the source of the duty". Collins, 2007a, p. 120.

125 See Articles 2 and 174, (1) (2) ECT and Article 37, Nice Charter.

126 See also: Desgagne, 1995, p. 296.

127 Ermacora has argued that "In fact, there are several positive effects justifying the necessity of enshrining the human right to a clean environment: firstly, it would be to enhance the clarity of the meaning and the boundaries itself, providing legal certainty and concentrating the aspects of such a right into one clause; secondly, to increase awareness of such a right by individuals who could feel more concerned and take legal (court) action to defend their environmental basic right and finally, because it could establish the equal ranking of environmental interests with such as the right to property which could be invoked in order to defend economic interests". Ermacora, 2003 p. 29; of the same opinion is Heldeweg, 2005, p. 22. 
the gap without having to wait on Charter revision action from the EU institutions could be through a procedural rights approach which has been developing since the entry into force of the Aarhus Convention. In other words, it could be the introduction of procedural environmental rights. It is worth remarking that a set of this kind of rights encompassing a right to access to information, a right to participation, and a right to access to justice has already reached a level of regional customary law in Europe through adoption of a number of regional legal instruments, agreements, and initiatives (Pedersen, 2010).

Another solution could be interpreting two Articles of the Charter in an environmentally friendly way: Article 37 could be read together with the right of access to documents provided by Article 42 and the right to an effective remedy provided by Article 47 . The terms used in both provisions are quite vague, but it has been suggested that they could be greening in accordance with obligations emerging also from Articles 4 and 9 of the Aarhus Convention. ${ }^{128}$ Concerning public participation, Article 6 of Aarhus and Article 11 of the Lisbon treaty could be linked.

Moreover, the $\mathrm{EC}$ ] could directly use the Aarhus Convention: for example, by reviewing any secondary EU legislation which does not follow the international obligations incumbent on the Community as party to the Convention. ${ }^{129}$ Moreover, now that the Charter, as it has become primary Community law, has become subject to the jurisdiction of the EC] (Collins, 2007a), this could also lead to a broadening of the scope of Article 37 (Pedersen, 2010). In fact, the Charter establishes that it should not be interpreted as restricting or adversely affecting rights and freedoms set forth under international law, including the European Convention on Human Rights. The EC], hence, could co-ordinate efforts towards environmental rights in Europe by making a direct link with the Aarhus Convention and existing secondary EU legislation implementing the Convention.

128 "By linking the body of law surrounding the Aarhus Convention in the EU to Article 37,42 and 47 of the Charter the EC] could streamline environmental democracy efforts in the EU legal space", Hectors, 2008, p. 165.

129 Case C-239/03 Commission v. France [2004] ECR 1-9325. In the Etang de Berre case, the EC] holds "that specific implementation of an environmental protection was unnecessary, since the mere accession of the Community to this Convention created Community obligations on the states". Eleftheriadis. 2007. See also EC] 15 October 2009, In Case C-263/08. 
2.2.1.1.3. Where Can We Find the European Environmental Substantive Rights? So even if EU law does not expressly provide a right to an adequate environment, a kind of recognition of the right to a healthy environment per se at the EU level may be found elsewhere. There are different approaches by scholars.

According to some authors, the sources of this right might be found in the precautionary principle provided in former Article 174 of the Treaty. This principle in brief states that when an activity raises threats of harm to human health or the environment, precautionary measures should be taken even if cause and effect relationships are not fully established scientifically. In fact, Miller writes that this a "powerful and comprehensive principle which, in conjunction with the right to information on discharges and rights conferred by other directives, would appear to endow citizens of the European Union with the fundamental right to an environment adequate for (human) health and well-being" (Miller, 1995, p. 374).

Thus the principle encompasses "a presumption in favour of ordinary citizens' right to protection from environmentally hazardous activities, and places the burden of proof on proponents of a new technology, activity, process, or chemical to show that it does not pose a serious threat" (Hayward, 2000, p. 168). So, although the precautionary principle has undeniable importance in giving substantive meaning to environmental rights, the inherent uncertainties involved in interpreting and applying it mean that the principle cannot in itself be considered a source of rights nor create a fundamental environmental right.

Moreover, following another approach, it has been suggested that the right to environment emerges from the Community's secondary law on procedural environment rights. Indeed, the EU has promulgated an immense body of environmental protection legislation which may constitute an implicit recognition of the right to environment, but this question will be explored later.

Finally, there is the opinion that points out the jurisprudence of the European Court of Human Rights. The silence of the European Convention on Human Rights on the environmental issue, has, however, not stopped the Court, set up under the Convention, from developing jurisprudence in relation to the environment. Indeed, as the European Court of Human Rights has often affirmed "the Convention is a living instrument, which must be interpreted in the light of the present-day condition" (Mularoni, 2008, p. 231).

Space does not permit a discussion of all of the different approaches mentioned above, so it will be interesting to see the development of the jurisprudence of the European Court of Human Rights concerning this right, since the judiciary has already demonstrated a willingness to take a teleological approach to human rights in an environmental friendly manner. Moreover, as already mentioned, the jurisprudence is more important since the entry into force of the Lisbon Treaty, which has recognised that the European Union shall accede to the European Convention on Human Rights. 


\subsection{ECHR Jurisprudence: Environmental Protection "Par Ricochet"}

Following part of the doctrine, one way to develop a right to environmental protection is to interpret existing human rights in an environmentally friendly way. This "greening" (Pasques, 2006, p. 40) process has been an opportunity the ECHR has taken during the last decade (Hectors, 2008, p. 168). Thus, the Court has mobilised existing human rights (Anderson, 1996, p. 4) to recognise the link with environmental protection, e.g. to reach indirectly a recognition of an environmental right. ${ }^{131}$

Article 2 of the European Convention provides a right to life which is understood as protection against the arbitrary deprivation of life by the state, but at the same time as a positive duty on states to take the necessary measures to protect human life. The Court has affirmed that the bad conditions of the environment may influence human life; consequently, among the duties of the state there is also the duty to protect the environment. ${ }^{132}$

Moreover, the most frequently invoked human right in the environmental field against environmental degradation affecting individuals is the right to respect for private and family life, and for the home, as guaranteed in Article $8 .{ }^{133} \mathrm{It}$ has become well-established that serious environmental damage may lead to a violation of this Article. Other substantive human rights which have been "greening" are the right to property ${ }^{134}$ and the procedural guarantees enshrined in Article 6 (Schall, 2008, p. 417).

It is interesting to note that the Strasbourg Court does not "attach to environmental protection a significant symbolic value to stand on its own as a fundamental right"; rather, it is a condition for the enjoyment of existing fundamental rights. Unfortunately, as has been remarked, the consequence of this approach entails that the protection of the environment "would 'lose' every time it conflicts with existent fundamental rights" (De Abreu Ferreira, 2007a, p.

130 See in particular: Sudre, 2001, p. 275.

131 On the analysis of the ECHR' jurisprudence on human rights and environmental protection see inter alia Déjeant-Pons, 2002, p. 23; Frumer, 1998, p. 813; McManus, 2005. p. 575.

132 Oneryildiz v. Turkey (2005) 41 EHRR 20, [65].

133 Article 8 reads: " 1 . Everyone has the right to respect for his private and family life, his home and his correspondence. 2. There shall be no interference by a public authority with the exercise of this right except such as is in accordance with the law and is necessary in a democratic society in the interests of national security, public safety or the economic well-being of the country, for the prevention of disorder or crime, for the protection of health or morals, or for the protection of the rights and freedoms of others".

134 Athanassoglou v. Switzerland (2001) 31 EHRR 13; Nevertheless the court's jurisprudence on Articles 8 and 10 can sometimes conflict with the right to property enshrined in Article 1 of Protocol 1 to the ECHR. 
5). In this situation, the choice when the environment "wins or loses" is taken by the State and so the applicant bears the burden of proof to show that the State has gone beyond its margin of discretion and its choice was wrong (De Abreu Ferreira, 2007a).

\subsection{Jurisprudences of ECHR in Environmental matters}

The first direction taken by the Court, in 1976, was that no right to preservation of the natural environment as such was included among the Convention's rights. ${ }^{135}$ Nevertheless, some time later that view started to change: the Commission noted in 1990 in S. v. France that considerable noise and other nuisances could undoubtedly affect the well-being of a person and thereby interfere with the Convention's rights. ${ }^{136}$

This new approach was followed by the Court in Powell v. United Kingdom in $1990 .{ }^{137}$ Nevertheless, the first real step to align the ECHR with environmental protection was taken in the famous judgement López Ostra v. Spain, where

135 See X. v. Germany, App. No. 7407/76, 5 Eur. Comm'n H.R. Dec. \& Rep. 161, 161 (1976), The case concerns dismissing the applicants' claims that military activities in marshlands violated right to life, prohibitions on torture and inhuman treatment, and rights to liberty and security.

136 See S. v. France, App. No. 13728/88, 65 Eur. Comm'n H.R. Dec. \& Rep. 250, 26364 (1990) (nuisances stemming from construction of a nuclear power plant could not be considered disproportionate to the legitimate interests served by the operation of the plant, especially in light of compensation already received by applicant). See also Arrondelle v. United Kingdom, App. No. 7889/77, 26 Eur. Comm'n H.R. Dec. \& Rep. 5, 8-9 (1983).

137 Powell v. United Kingdom, 172 Eur. Ct. H.R. (ser. A) 1 (1990).The case related to the effects of noise levels emanating from Heathrow Airport on citizens living in close proximity. The applicants argued that the noise levels amounted to a violation of Articles 6 , 8 , and 13 of the ECHR. The court noted that Article 8 was a material provision in assessing the case, as the applicants' lives had been adversely affected by the noise. Article 8 deals with the right to respect for private and family life while also setting out the circumstances under which a possible infringement may be justified. However, the court held, while noting the central role that Heathrow Airport plays in the U.K. economy, that the measures taken by the United Kingdom in relation to noise abatement were within the margin of appreciation and in this light it was not for the court to substitute its own assessment for that of the United Kingdom, concerning what might constitute the best policy. Likewise, the court in Hatton v. United Kingdom (Hatton v. United Kingdom, 2003-VIII Eur. Ct. H.R. 189, 228 (2003)) found that the nuisances from night flights to and from Heathrow Airport did not amount to a violation of Article 8 . Although the court noted that "environmental protection should be taken into consideration by States in acting within their margin of appreciation [...] it would not be appropriate for the Court to adopt a special approach in this respect by reference to a special status of environmental human rights". It stressed the positive impact of the airport on the U.K. economy, combined with the relatively slight impact the noise had on house prices and the chances for the applicants to comment on government policy on night flights, in finding that the government had struck a fair balance. By stressing the economic importance of the flights, the court left a rather wide margin of appreciation for the member states as environmental disputes often amount to 
the Court identified a violation of Article 8 of the Convention as a result of environmental conditions. Although the court refrained from fashioning a substantive right to the environment under the ECHR, it found Spain violated its positive obligation to ensure López Ostra could live in an environment that did not constitute a serious health threat to her and her family.

Another leading case is Guerra v. Italy. ${ }^{138}$ The Court affirmed that the Italian authorities had failed in their positive obligation under that provision to secure effective respect for the applicants' right to family life. ${ }^{139}$ The Court construed the right to privacy as guaranteeing protection against environmental pollution. ${ }^{140}$

Moreover, the precedent created by the two mentioned cases has subsequently been confirmed in Taskin v. Turkey, ${ }_{1}^{141}$ where the Court held that Turkey, by using sodium cyanide in gold extraction in defiance of domestic court decisions, had violated Article 8 . The importance of this judgment is based on two levels.

First, the judgment includes a number of references to the applicants' right to a healthy environment under the Turkish Constitution and then shows that a "domestic guarantee of the right to environment may have substantial legal significance at the supranational level" (Collins, 2007a, p. 120).

Even more significant in this statement is the Court's recognition of the right to environment in international law, referring to the relevant international texts on the right to a healthy environment" and to the procedural environmental rights enshrined in the Rio Declaration ${ }^{142}$ and the Aarhus Convention. Furthermore,

a balancing act of economic interests on one side and environmental considerations on the other. Pedersen, 2010.

138 In Case of Guerra and Others V. Italy (116/1996/735/932), Judgement ECHR, 19 February 1998. Here, the applicants alleged that the Italian authorities violated Articles 2 , 8 , and 10 by failing to mitigate the risk of a major accident at a nearby chemical factory and by withholding information from local residents about the risks and about what emergency procedures were in place. The chemical factory was deemed a "high risk" according to Italian law (an explosion at the plant in the 1970s had led to the hospitalisation of 150 people). De Abreu Ferreira, 2007a, p.5

139 It is also worth noting that however, there are a number of cases where no violation has been found. For instance, in Buckley v. United Kingdom, 1996-IV Eur. Ct. H.R. 1271, 1287, 1996. See also Johannische Kirche v. Germany, App. No. 41754/98 (2001), available at European Court of Human Rights HUDOC Search Portal, available at www.cmiskp.echr. coe.int/tkp197/search.asp?skin=hudoc-en. See Kyrtatos v. Greece, App. No. 41666/98, 40 Eur. H.R. Rep. 390 (2005).

140 See generally Sands, 1999, p. 39.

141 ECHR 10 November 2004, Taskin v. Turkey, 2004-X Eur. Ct. H.R. 145 (2005).

142 Declaration on Environment and Development, Principe 1, Report of the UN Conference on Environment and Development (UNCED). The UNCED was held in Rio de Janeiro (Brazil) from 3 to 14 June 1992 and was attended by 178 States, more than 50 intergovernmental organisations and several hundred non-governmental organisations (NGOs). The European Union also attended the Conference. In addition to the signing by 
it is interesting to note that "the Court also unites procedural environmental rights, the right to environment, and the preservation of existing rights through environmental protection all under the rubric of the "right to a healthy environment". It seems that it may be perceiving the right to environment as one "unitary right", encompassing both substantive and procedural aspects (Collins, 2007a, p. 146).

Also interesting in this respect is the case of Oneryildiz $v$. Turkey, ${ }_{1}^{143}$ where the Court affirmed that an environmental disaster can violate many rights contained in the Convention. Thus, it declared that the Turkish action was in contrast with Articles 2, 8 and 13 concerning the right to an effective remedy for violation of Convention rights, and with Article 1 of Protocol No. 1 relating to the right to peaceful enjoyment of possessions. ${ }^{144}$

The López Ostra and Guerra precedents were confirmed in Moreno Gómez v. Spain, ${ }^{145}$ concerning noise pollution. Here, the Court found a breach of Article 8 as a result of the noise generated from an area with a high concentration of nightclubs and bars, after noting that the authorities had lacked a willingness to enforce existing rules which were designed to abate the noise levels. The court made similar findings in Fadeyeva v. Russia, ${ }^{146}$ involving pollution from the

more than 150 States of the United Nations Framework Convention on Climate Change and the Convention on Biological Diversity, the Conference adopted three non-binding instruments: the Rio Declaration, the UNCED Forest Principles and Agenda 21.

143 ECHR 18 June 2002 and 30 November 2004.

144 The applicants claimed that Turkey was responsible for the deaths of their close relatives and the destruction of their property resulting from a methane explosion at a nearby municipal waste dump. See Collins, 2007a, p. 120.

145 ECHR 16 November 2004, Moreno Gómez v. Spain, 2004-X Eur. Ct. H.R. 327, 343 (2005).

146 ECHR 9 June 2005, Fadeyeva v. Russia, Application No 55723/ 00, Reports of Judgments and Decisions 2005-IV. The applicant in Fadeyeva lived in the Russian town of Cherepovets, approximately 450 meters from a steel plant. According to official reports, the Soviet-era plant contributed more air pollution than any other metallurgical plant in Russia, and its emission levels exceeded domestic standards. Throughout the years, the authorities had created a so-called "sanitary security zone" in order to protect people living in the area, but the zone had on a number of occasions been reduced. In addition, the authorities had, without effect, ordered the inhabitants of the "sanitary security zone" to resettle and failed to offer them any effective assistance in their attempt to resettle. Furthermore, the court hinted at the procedural norms enshrined in Article 8 in cases of environmental decisions when noting that "there is no indication that the State designed or applied effective measures which would take into account the interests of the local population affected by the pollution, and which would be capable of reducing the industrial pollution to acceptable levels". Fadeyeva, 2005-IV, Eur.Ct.H.R.at 292-293. 
Severstal steel plant, the largest iron smelter in Russia, and also in Giacomelli v. Italy, ${ }^{147}$ which involved storage and treatment of "special waste".

It is worth noting that the Court has also acknowledged the importance of procedural environmental rights as in the case Taskin v. Turkey and other decisions. In fact, procedural rights present a remedy in the European human rights machinery regardless of the court's caution towards recognising a substantive right, and offer adjudication in cases where national authorities pay little attention to the link between human rights and the environment. Thus, the Court has extended the procedural scope of Article 8 to include not only access to certain environmental information but also limited participation and subsequent redress before judicial authorities.

For instance, in Vides Aizsardzibas Klubs v. Latvia, ${ }^{148}$ a Latvian court affirmed "a defamation suit by a mayor based on public allegations of impropriety made by an environmental NGO and the Court declared that Article 10 of the Convention has been violated by the Latvian Court, because the NGO "acted as an environmental "watch dog" ("chien de garde") and that this function was an essential one in a democratic society" (Collins, 2007a, p. 142).

In summary, it may be concluded that, although the ECHR has refrained from an explicit creation of a substantive right to the environment, the court's jurisprudence represents a significant contribution to the status of environmental rights (Hodkova, 1991, p. 70).

\subsubsection{Ecological European Citizens}

The creation of an environmental consciousness and a responsibility vis-à-vis the environment has started to develop at the European level ${ }^{149}$. If individuals

147 ECHR 2 November 2006, Giacomelli v. Italy. The court found an Article 8 violation in this last case, where the decision to issue an operating license to a waste treatment facility had not been accompanied by an environmental impact study in accordance with domestic law.

148 ECHR 27 May 2004 ECHR 27 May 2004.

149 Concerning responsibility vis-à-vis the environment Parola (2013) underlines that: "As a counterbalance to the rights-based approach which offers only indirect and limited ecological protection and reinforces the anthropocentric value system that is at the root of ecological degradation, there is an additional view. What is necessary is more emphasis upon the adoption and exercise of responsibilities towards all life, including non-human life (P. Taylor, 2009, p. 89), and a special responsibility to "care for the planet" (Weiss, 1990, p. 199). Increasingly, it is being pointed out that in many cultures individuals have duties and responsibilities towards others and the wider community. Traditionally, the duty-approach offers a subordinated prospective. Nevertheless, during the French Revolution the idea that citizenship is more about duties towards the Republic than rights was dominant. The slogan "no rights without responsibilities" is starting to take a new 
are aware that their actions as consumers or direct producers of pollution may have negative effects on the environment, this may motivate individuals to change their action, and ecological duties can be implicitly recognised through participatory rights. Thus, there is a relationship between rights and duties in an environmental approach. ${ }^{150}$

Indeed, public participation is claimed to enhance active ecological citizenship since granting environmental rights leads to taking environmentally responsible private decisions as well (Lee, 2005, p. 125). An example which could explain this link is the access to information: granting this right provides citizens with the necessary information to better judge and evaluate and, finally, to make the environmentally friendly choice.

As pointed out above, in the notion of Environment in Europe the anthropocentric prospective is preeminent, although not exclusive. Hence, there is an implicit rejection of ecological thought. Nevertheless, as will be seen in the next section, the EU has recognised some aspects of the citizens' duty vis$\grave{a}$-vis the Earth and not just future generations, as is reflected in several policy instruments in the EU.

It has been stated in the book "Environmental Democracy at Global Level" (Parola, 2013) that there are two fundamental characteristics of ecological citizenship: first, ecological citizenship might be recognised as a non-territorial form of citizenship due to the fact that it extends beyond territorial boundaries

position in modern green political thought. Indeed, the other face of environmental rights presumes an active attitude on behalf of citizens, and even more, a citizens' duty to protect the environment. Each person has the right to have his or her environment protected, but is also obliged to contribute to the common effort". "Thus, there are two fundamental obligations, one to present and future generations, and another to nature". "Philosophy, religion, green political thought and some legal traditions from diverse cultural traditions have already recognised that man is trustee or steward of the natural environment and from this arises man's duty to conserve the planet for present and future generations. Nevertheless this recognition is not universal and almost all environmental theories note there is a huge lack of inter-generational and intra-generational equity. First, political leaders fail to adequately consider future interests in evaluating policy options. But "this myopia" is not the outcome of a lack of a concern for children or future inhabitants of Earth; instead, it is "the result of institutional constraints that encourage political leaders to prioritise the short-term needs of voters" (Wolfe, 2008, p. 1897)". "The second obligation is the duty to protect the environment, e.g. the living and non-living creatures. This duty is reflected in the principle of sustainability and cannot be confused with shallow versions of sustainable development. The indispensable element of the new categorical imperative is responsibility for the community of life (Bosselmann, 2008). If translated to political theory, responsibility for all life requires a total rethinking of law and governance".

150 Moreover, duty-centered approaches can also be found also in some national constitutions of Member States, including duties both of individuals, (The Spanish Constitution) and of government (for example the Dutch Constitution). 
of the nation-state, and secondly, these kinds of duties embody both the private and public sphere.

Concerning the non-territorial boundaries it can be noted that this feature characterises the EU vision as well; in fact, it has been decided that more and more issues must be regulated between the 27 States as the boundaries do not exist anymore.

Indeed, the awareness that ecological issues and the protection of the environment surpass political delimitations between the States is already demonstrated by several directives which try to regulate environmental transboundary problems. An example is the Water Framework Directive ${ }^{151}$ which promotes a new ecological and transboundary approach to water management. The new WFD rationalises and updates existing water legislation by setting "common" EU-wide objectives for water. The first recital states the importance of water as such and the necessity to adopt legal provisions to protect it. The recital reads as follows: "Water is not a commercial product like any other but, rather, a heritage which must be protected, defended and treated as such".

This recital is linked with recital 19 announcing the main purpose of the WFD: "This directive aims at maintaining and improving the aquatic environment in the Community". To achieve this aim the Member States have to designate river basin

151 Directive 2000/60/EC establishing a framework for Community action in the field of water policy as amended by Decision 2455/2001/EC and Directive 2008/32/EC. The WFD builds the foundation of a modern, holistic and ambitious water policy for the European Union. The decision for establishing a new framework for water management in Europe happened within a changing social and political framework. The increasing internationalisation and complexity of water resource management, the increasing number of actors and institutions involved in this process, the newly vested economic interests in water supply, and the increasing concern and sensitivity towards environmental protection, are amongst these factors After meetings and consultations the Commission proposed in 1997 the draft of a framework directive that promotes a new ecological and transboundary approach of water management and in 2000 the "Directive 2000/60/EC of the European Parliament and of the Council establishing a framework for the Community action in the field of water policy" was adopted. The WFD establishes a framework for the protection of all water bodies, which prevents further deterioration of water resources, promotes sustainable water use and ensures the progressive reduction of pollution of water bodies. This is because the WFD requires MS to aim to achieve 'good ecological and chemical status' in surface waters and 'good chemical and quantitative status' in groundwaters by 2015. It will do this by establishing a river basin district structure within which demanding environmental objectives will be set, including ecological targets for surface waters. The Directive sets out a timetable for both initial transposition into laws of MS and thereafter for the implementation of requirements. The WFD promotes the integrated management of water resources to support environmentally sound development and reduce problems associated with excessive water abstraction, pollution, floods, ancestry programmes at the river basin scale and, in many cases, transboundary collaboration between European countries. 
districts ${ }^{152}$ and competent authorities for the river basins. ${ }^{153}$ The Member States are under a duty to assign river basins extending to more than one Member State to an international river basin district. In such an international river basin district, the MS shall ensure the coordination of their national measures..$^{154}$ Finally, river basins extending into non-member states are subject to a less strict duty to ensure coordination. ${ }^{155}$

Furthermore, the idea of freedom of movement of citizens has grown from the idea of elimination of boundaries and also from the idea of achieving a citizenship arising from a deeper integration of Europe. In environmental matters there are also some attempts in this direction. In fact EU measures to introduce elements of Participatory Democracy in environmental matters have begun to expand notions of citizenship on environmental issues beyond the nation state. Thus, an ecological perspective to citizenship leads a "disruptive challenge to the traditional notion of citizenship", one which looks "outside the city, beyond the public, and further afield than the nation-state" (McGillivray, \& Holder, 2001, p. 168).

Another example which demonstrates a movement towards the loosening of the concept of boundaries is the revised Directive on Environmental Impact Assessment which requires public consultation within other member states which may experience significant environmental effects through developments outside of their borders (McGillivray, \& Holder, 2001, p. 169).

Thus, from the above-mentioned examples it can be affirmed that at the EU level there is a growing idea to eliminate boundaries between States when the protection of the environment is at stake, as well as the recognition of a common European natural heritage. The idea of a common natural heritage in Europe "ought therefore to elevate the relationship between community and environment to a higher plane, in the process creating a more direct connection between individuals and the environment" (McGillivray, \& Holder, 2001, p. 170).

Passing now to the second feature of ecological duties which are embodied both in the private and public sphere, evidence of this character in EU policy and legislation is emerging. For example, the public right to participate can also be read as a public duty to participate even if there is no legal obligation. Granting procedural environmental rights can thus mean giving the possibility to the

152 The adoption of the river basin approach means that water protection measures attached to "the area of land from which all surface run-off flows through a sentence of streams, rivers and possibly, lakes into the sea at a single river mouth, estuary or delta". Article 2 of WFD.

153 Article 3 (1) (2) of WFD.

154 Article 3 (4) of WFD.

155 Article 3 (5) of WFD. 
citizens to be involved and at the same time also improve their idea that they should feel involved in order to defend their environment.

Of course, the private sphere is more linked to the duties approach. There is, after all, much in the belief that "from an ecological point of view, good citizenship is learnt in private, not in public" (McGillivray, \& Holder, 2001). Following this perspective the EU has tried to enforce directly or indirectly this duties approach in the private sphere, for instance, through waste regulation, environmental crimes, environmental liability and eco-labelling (Makuch, 2004, p. 226).

In conclusion, hence, it can be said that some aspects of ecological citizenship already exist and they could also lead to greening of the European citizenry. The following part will focus on finding the legal basis of ecological duties. ${ }^{156}$

\subsubsection{Ecological Duties}

Concerning this subject there are two questions to answer: are there some sort of statements with regard to ecological duties in EU law? Or are there some principles which can be used to implement those duties?

The first question can be answered by stating that at the moment the EC treaty has not yet recognised explicitly ecological duties. Nevertheless, implicitly such duties are emerging. There are some principles that carry this notion, in particular some which embody the duty to protect the environment and likewise to repair it.

Those principles are the Precautionary Principle, the Preventive Principle, the Sustainable Development Principle and the Polluter Pays Principle, all provided

156 It has to note there is in Europe, a corporate social responsibilities movement which are becoming an official government policy in many countries and in July 2001 the Commission issued a Green Paper on a European framework for corporate social responsibilities (COM (2001) 366 final). This policy concerns not the responsibility of the citizen but the citizen as producer. "The Green Paper discusses issues such as what is corporate social responsibility, the internal dimension of CDR, including human resources management, health and safety at work and management of environmental impacts and natural resources, CSR's external dimension, which involves stake-holders such as local communities, business partners, consumers, and activist groups and CSRintegrated management, reporting and auditing". How it has been underlined that "the treatment of these issues in the Green Paper is repetitive and fuzzy, and fails to address the fundamental issues. Unfortunately, this representative of the CSR proponents' thinking". The CSR, as define by the Green Paper, is "a concept whereby companies decide voluntarily to contribute to a better society and a cleaner environment". Thus "although the prime responsibility of a company is generating profits, companies can at the same time contribute to social and environmental objective, through integrating corporate social responsibility as a strategic investment into their core business strategy, their management instruments and their operations". Bergkamp, 2002, p. 136. 
for in former Article 174 (2) (now Article 191). It is worth underlining that there are other principles, laid down by that Article, like the high level of Protection Principle, the Source Principle and the Safeguard Clause, but those principles are set out in particular for Community legislation and it is difficult to find a ink with individual and citizens' duties. ${ }^{157}$ Space does not permit the analysis in detail of the above-mentioned principles. Nevertheless, a word must be said about how those principles involve ecological duties.

\subsection{Preventive Principle and Precautionary Principle}

The preventive principle already played a role in European environmental law before it was inserted into the European Treaty through the Single European Act, since it previously had been enshrined in the first three environmental action programmes. ${ }^{158}$ From that moment on, secondary environmental legislation of the Community started to reflect this principle as well. ${ }^{159}$ The preventive

157 For instance Precautionary Principle and preventive action. Both principles have at the basis the idea to act before damage to the environment occurs, thus of course it is linked to the duty to protect. Nevertheless for our purpose those principles are not so fundamental in the view to the citizens' duty. As will be seen later, those principles can also be applied to the citizens' duty to restore and pay for environmental damage. In fact, the Sustainable considerations and the precautionary principle could perhaps be used in connection to environmental crimes. For instance, in cases concerning endangerment crimes, the precautionary principle could lead a judge to be "more severe with defendants who did not bother to explore all the possible consequences of their acts and might thereby have exposed society to clear risks". See Westerlund, 2008, p. 503.

158 First Environmental Action Programme of the European Community of 1973, O] 1973. C 112/l; Second Environmental Action Programme of the European Community of 1977, O] 1977, C 139/l; Third Environmental Action Programme of the European Community of 1983, O] 1983, C 46/I

159 E.g. Preambular 34 of Directive 2009/16/EC of the European Parliament and of the Council of 23 April 2009 on Port State Control, OJ 2009, L 131/57; Preambular 2 of Directive 2009/41/EC of the European Parliament and of the Council of 6 May 2009 on the Contained Use of Genetically Modified Micro-Organisms, O] 2009, L 125/75; Standard A 4.1 (1) (d) of Council Directive 2009/13/EC of 16 February 2009 implementing the Agreement concluded by the European Community Ship owners' Associations (ECSA) and the European Transport Workers' Federation (ETF) on the Maritime Labour Convention, 2006, and amending Directive 1999/63/EC, O] 2009, 124/30; Preambular 30 of Directive 2008/98/EC of the European Parliament and of the Council of 19 November 2008 on Waste and Repealing Certain Directives, O] 2008, L 312/3; Article 3(1)(a) of Directive $2008 / 1 / E C$ of the European Parliament and of the Council of 15 January 2008 Concerning Integrated Pollution Prevention and Control, O] 2008, L 24/8; Article 1(1)(b) of Council Directive 2006/88/EC of 24 October 2006 on Animal Health Requirements for Aquaculture Animals and Products Thereof, and on the Prevention and Control of Certain Diseases in Aquatic Animals, OJ 2006, L 328/14. 
principle is based on the assumption that it is better to prevent environmental harm than to cure it. ${ }^{160}$

Therefore, the principle involves a risk assessment to avoid harm (Kiss, \& Shelton, 1993, p. 37). Harm can only be prevented if the possibility of this harm is known. Due to this risk assessment, the principle has been expanded and complemented by the more complex precautionary principle. ${ }^{161}$

Only broadly described, the precautionary principle requires that an action against a potential environmental harm has to be taken even in the absence of scientific certainty that this harm will really occur (Louka, 2004, p. 20). The preventive principle can appear in two forms. It can either anticipate environmental damage in its entirety or it can try to anticipate the spread of already-occurred damage (De Sadeleer, 2002, p. 61).

As it will be shown later, this principle is reflected in the Liability Directive which pushes to enhance the citizens' ecological duties to protect and repair the environment.

\subsection{Sustainable Development}

Sustainable Development is linked to the recognition of the duty to protect the Environment vis-à-vis inter- and intra-generations, inter- and intra-species and Earth. This duty refers mainly to the European Union Institutions and Member States but it can also be used for their citizens. For current purposes, it is not possible to indulge on the theoretical basis of the obligation carried by this principle but it is worth analysing how this principle has been incorporated by the EU.

Sustainable development has a strong legal position among the ultimate objectives of the EU. As early as at the Rhodes Summit of 1988, the heads of government of the European Community, with reference to "environmental problems of increasing magnitude" declared Sustainable Development to be "one of the overriding objectives of all Community policies". ${ }^{162}$ This has been followed by several high level policy documents which affirm the significance

160 See on the subject: De Sadeleer, 2002, p. 61; Kiss, \& Shelton, 1993, p. 37; Krämer, 2003b, p. 25; Louka, 2004, p. 19.

161 See also: Krämer, 2003b, p. 25; Louka, 2004, p. 20.

162 Presidency Conclusions of the European Council, Rhodes, 2-3 December 1988 (DOC/88/10). At the same Summit, the government heads declared that the completion of 'the Single Market cannot be regarded as an end in itself, it pursues a much wider objective' and in the 'wider international context' the Community and the Member States declared their desire to play a leading role in achieving 'a better quality of life for all the peoples of the world' (Annex 1). 
of environmental protection, especially when linked to the goal of sustainable development. ${ }^{163}$

This principle is one of the tasks of the European Community under Article 2 EC and remains so under the new Treaty of Lisbon. Article 3(3) of the amended Treaty states the objectives of the EU and defines the principle of sustainable development in Europe with its three elements, namely economic, social and environmental. The wording of the definition has been changed from that in Article 2 of the TEC with regard to the social element of Sustainable Development.

However, the commitments to the environment are maintained through the use of similar words: "The Union shall establish an internal market. It shall work for the sustainable development of Europe based on balanced economic growth and price stability, a highly competitive social market economy, aiming at full employment and social progress, and a high level of protection and improvement of the quality of the environment. It shall promote scientific and technological advance". This reference broadens the scope of implementation of the principle beyond the jurisdictional boundaries of Europe to the world.

Another novelty in this Article is the recognition of sustainable development as one of the specific policy goals of the EU in its foreign relations as well, in particular where the Union expresses its will to work to: "foster the sustainable economic, social and environmental development of developing countries, with the primary aim of eradicating poverty; [...] help develop international measures to preserve and improve the quality of the environment and the sustainable management of global natural resources, in order to ensure sustainable development". ${ }^{\prime 164}$

Moreover, a new ecocentric view may be found in Article 3(5): "In its relations with the wider world, the Union shall uphold and promote its values and interests and contribute to the protection of its citizens. It shall contribute to peace, security, the sustainable development of the Earth, solidarity and mutual respect among peoples, free and fair trade, eradication of poverty and the protection of human rights, in particular the rights of the child, as well as to the strict observance and the development of international law, including respect for the principles of the United Nations Charter". ${ }^{165}$

Thus, the duty to protect the environment is a fundamental objective of the EU but it has to be implemented into more concrete legal duties for European citizens.

163 E.g. Presidency Conclusions of the Brussels European Council 15-16 June 2006 (10633/1/06 REV 1). Sjafjell, 2010.

164 Article 21(2)(d) and (f) TEU.

165 Article 3(5) TEU 


\subsection{Polluter Pays Principle}

Concerning the duty to repair the environment, the Polluter Pays Principle (PPP) carries the idea that in the case of the environment being damaged by an individual, from this harm arises the duty to repair. ${ }^{166}$

The PPP has existed in Community law since 1973. ${ }^{167}$ However, it was not until 1987 that it found its way into the text of the EC Treaty (De Sadelee, 2002, p. 30), ${ }^{168}$ following the entry into force of the Single European Act of $1986 .{ }^{169} \mathrm{It}$ is one of the fundamental principles of European environmental policy and it is enshrined in the new Article 191 of the EC Treaty and in numerous secondary legislation of the Community. ${ }^{170}$ It mainly means that the costs resulting from a polluting act should be borne by the person who caused the pollution and not by society as such (Sadeleer, 2002, p. 21). ${ }^{171}$ The formulation of the principle leaves some questions open (Grossman, 2006, p. 29), such as: who is actually the polluter who shall bear the costs, (Sadeleer, 2002, p. 38)172 and which costs exactly must the polluter bear? (Sadeleer, 2002, p. 42; Grossman, 2006, p. 13).

Concerning the question regarding which costs the polluter must pay, the principle has undergone a change. In the beginning, the costs merely comprised the costs of pollution prevention and control and now the principle also extends to costs of restoration (Grossman, 2006, p. 30). Furthermore, the principle is

166 See in general about the PPP: A. Bleeker, 2009, p. 289.

167 First Environmental Action Programme of the European Community of 1973, O] 1973. C 112/l; Second Environmental Action Programme of the European Community of 1977, OJ 1977, C 139/l; Third Environmental Action Programme of the European Community of 1983, O] 1983, C 46/l; first formal articulation at the European level of the principle had been made already one year earlier in the OECD Guiding Principles Concerning International Economic Aspects of Environmental Policies, OECD Doc. C $72 / 128$ at para. 4 .

168 See also: Grossman, 2006, p. 11; Larsson, 1999, p. 90; Thornton, \& Beckwith, 2004, p. 84 .

169 OJ 1987, L 169/1

170 See e.g. Preambular 2 of the Directive 2008/1/EC of the European Parliament and of the Council of 15 January 2008 concerning integrated pollution prevention and control, O] 2008, L 24/8; Preambular 14 and Article 15 of the Directive 2006/12/EC of the European Parliament and of the Council of 5 April 2006 on waste, O] 2006, L 114/9; Preambular 11, 38 and Article 9 of Directive 2000/60/EC of the European Parliament and of the Council of 23 October 2000 Establishing a Framework for Community Action in the Field of Water Policy, O] 2000, L 327/1; Article 15 of Council Directive 91/156/EEC of 18 March 1991 Amending Directive 75/442/EEC On Waste, O] 1991, L 78/32.

171 See also: Kiss, \& Shelton, 1993, p. 39; in general Larsson, 1993, p. 90; Louka, 2004, p. 16; Thornton, \& Beckwith, 2004, p. 84.

172 See also: Grossman, 2006, p. 3; Krämer, 2003b, p. 28; Thornton, \& Beckwith, 2004, p. 84; Louka, 2004, p. 16. 
seen to have shifted from a merely economic principle to a liability principle (Sadeleer, 2002, p. 33). This will be shown in the following.

Hence, the principle can be enforced by various means, requiring producers or resource users to meet the cost of implementing environmental standards or technical regulations, or by introducing liability regimes that hold producers liable for causing environmental damage. The proposed Sixth Environmental Action Programme provides a clear signal to this effect by proposing the following commitment for the coming decade: "To promote the polluter pays principle, through the use of market based instruments, including the use of emissions trading, environmental taxes, charges and subsidies, to internalize the negative as well as the positive impacts on the environment" (Coffey, $\&$ Newcombe, 2001).

All the above instruments can provide incentives for introducing more environmentally sensitive practices, thereby providing clear incentives to alter behaviour; more importantly, this principle can be read in the prospective of a duty to repair.

\section{Conclusion of Chapter 1}

It can be said that from a democratic perspective, the EU has tried to find a solution to the democratic deficit by introducing some elements of participatory and deliberatory democracy.

Democracy, recognised at the EU level in particular as confirmed and extended by the Lisbon Treaty, is on the one hand a representative democracy which encompasses elections, political parties, governments by elected officials, and on the other hand, is a participatory and deliberative democracy which involves, for example, citizen initiatives and the recognition of other participatory rights such as access to information. Although an effort exists to shift towards a participatory model, it cannot be viewed as an achieved goal; what's more, the issue of the EU's democratic deficit primarily as a question of the balance of power between the institutions rather than as being concerned with the relationship of the citizens to these institutions should be resolved.

Section I has analysed the relationship between "Europe" and "Environment" and in particular the notion "Environment" which can be found in the European context can be divided into wide and narrow definitions and can be characterised by a mainly anthropocentric approach.

Nevertheless, this strong anthropocentric orientation should eventually be reduced as EU actions in certain fields which entail a more ecocentric approach, for instance, Climate Change, increase; also, some grains of the ecocentric approach have entered into EU environmental law provisions, in particular through EC] jurisprudence. 
The final part of Chapter I has, thus, emphasised that the theoretical model of Environmental Democracy as well as some features of the new citizenship and its environmental rights and ecological duties are starting to be recognised in the European Union. There are, as well, some signs of the EU's efforts to foster the role for citizens and NGOs in environmental fields through explored directives which implement the Aarhus Convention. 